\title{
On the viscosity of two 1-butyl-1-methylpyrrolidinium ionic liquids: effect of the temperature and pressure
}

Gaciño, Félix M.; Comuñas, María J.P.; Regueira Muñiz, Teresa; Segovia, José J.; Fernández, Josefa

Published in:

Journal of Chemical Thermodynamics

Link to article, DOI:

10.1016/j.jct.2015.03.002

Publication date:

2015

Link back to DTU Orbit

Citation (APA):

Gaciño, F. M., Comuñas, M. J. P., Regueira Muñiz, T., Segovia, J. J., \& Fernández, J. (2015). On the viscosity of two 1-butyl-1-methylpyrrolidinium ionic liquids: effect of the temperature and pressure. Journal of Chemical Thermodynamics, 87, 43-51. https://doi.org/10.1016/j.jct.2015.03.002

\section{General rights}

Copyright and moral rights for the publications made accessible in the public portal are retained by the authors and/or other copyright owners and it is a condition of accessing publications that users recognise and abide by the legal requirements associated with these rights.

- Users may download and print one copy of any publication from the public portal for the purpose of private study or research.

- You may not further distribute the material or use it for any profit-making activity or commercial gain

- You may freely distribute the URL identifying the publication in the public portal 


\section{Accepted Manuscript}

On the viscosity of two 1-butyl-1-methylpyrrolidinium ionic liquids: effect of the temperature and pressure

Félix M. Gaciño, María J.P. Comuñas, Teresa Regueira, José J. Segovia, Josefa Fernández

PII: S0021-9614(15)00059-2

DOI: http://dx.doi.org/10.1016/j.jct.2015.03.002

Reference: YJCHT 4169

To appear in:

J. Chem. Thermodynamics

Received Date: $\quad 26$ November 2014

Revised Date: $\quad 27$ February 2015

Accepted Date: $\quad 4$ March 2015

Please cite this article as: F.M. Gaciño, M.J.P. Comuñas, T. Regueira, J.J. Segovia, J. Fernández, On the viscosity of two 1-butyl-1-methylpyrrolidinium ionic liquids: effect of the temperature and pressure, J. Chem. Thermodynamics (2015), doi: http://dx.doi.org/10.1016/j.jct.2015.03.002

This is a PDF file of an unedited manuscript that has been accepted for publication. As a service to our customers we are providing this early version of the manuscript. The manuscript will undergo copyediting, typesetting, and review of the resulting proof before it is published in its final form. Please note that during the production process errors may be discovered which could affect the content, and all legal disclaimers that apply to the journal pertain. 


\section{On the viscosity of two 1-butyl-1-methylpyrrolidinium ionic liquids: effect of the temperature and pressure}

Félix M. Gaciño ${ }^{1}$, María J.P. Comuñas ${ }^{1}$, Teresa Regueira ${ }^{1,2}$, José J. Segovia ${ }^{3}$, Josefa Fernández $z^{1, *}$

${ }^{1}$ Laboratorio de Propiedades Termofisicas, Departamento de Física Aplicada, Universidad de Santiago de Compostela, E-15782 Santiago de Compostela, Spain

${ }^{2}$ Center for Energy Resources Engineering (CERE), Department of Chemistry, Technical University of Denmark (DTU), DK 2800 Kgs. Lyngby, Denmark

${ }^{3}$ Grupo de Investigación TERMOCAL-Termodinámica y Calibración, Universidad de Valladolid, Paseo del Cauce 59, 47011 Valladolid, Spain

*Corresponding author. Tel.: +34 881814046; fax: +34 881814112

E-mail address: josefa.fernandez@usc.es (J. Fernández) 


\section{ABSTRACT}

A new calibration procedure was used and four new temperature probes have been placed on a falling-body viscometer to improve its accuracy. The new configuration and calibration procedure allow measuring viscosities with an uncertainty of $3.5 \%$ at pressures up to $150 \mathrm{MPa}$. This device was employed to measure viscosities as a function of temperature and pressure for two ionic liquids (ILs): 1-butyl-1-methylpyrrolidinium tris(pentafluoroethyl)trifluorophosphate and 1-butyl-1-methylpyrrolidinium trifluoromethanesulfonate. Besides, we have measured the flow curves at pressures up to $75 \mathrm{MPa}$ and shear rates up to $1000 \mathrm{~s}^{-1}$ in a Couette rheometer. Dynamic viscosities were correlated as function of temperature and pressure with four different equations with average absolute deviation lower than 1\%. The pressure-viscosity and temperature-viscosity derived properties were analyzed and compared with those of other ionic liquids. Furthermore, experimental data were used to check the application of the thermodynamic scaling approach as well as the hard-sphere scheme. Both models represent the viscosity values with average relative deviations lower than $2 \%$.

Keywords: Ionic liquid, Viscosity, High Pressure, Thermodynamic Scaling, Hard Spheres Scheme. 


\section{Introduction}

A tribosystem is defined not only by their interacting surfaces, but also by its gap and the environment [1]. Lubricants are placed between interacting surfaces filling the gap to minimize the friction and wear. The lubricating performance of a fluid depends on the polarity of their molecules, their ability to form ordered adsorbed layers, their chemical and thermal stability as well as the thermochemical reactions which take place at the interface [2]. The lubricant forms a film whose thickness depends on how far apart the mechanical surfaces are, if they are in contact, how they move, as well as the viscosity of the fluid and its behaviour with pressure. Depending on these properties the fluid will be under a different regime of lubrication, which is commonly illustrated by the Stribeck diagram where the regimes are classified according to the film thickness and the friction coefficient. The Elastohydrodynamic Lubrication (EHL) regime is known as a type of fluid-film lubrication in which the mechanism of hydrodynamic film formation is enhanced by surface elastic deformation and lubricant viscosity increase due to high pressure [3]. Besides, under this regime, the surfaces are under high loads but not in direct contact, and for this reason the friction is lower than in other lubrication regimes. The film thickness is given, among other characteristics, by lubricant viscosity and its pressure-viscosity coefficient, therefore, to check the suitability of a fluid in this lubrication regime, both properties should be reliably determined.

To improve wear and friction performance new neat lubricants and oil additives are being considered. Ionic liquids (ILs) have been proposed as good candidates due to their unique properties $[4,5]$. They can be employed for applications involving extreme operating conditions on account of their high temperature stability and low vapor pressure [6]. Due to its high thermal conductivity, ILs dissipate heat more effectively during sliding [6,7], and can also reduce some non-desirable effects like abrasion [8,9]. However, one of the most important characteristic of ILs is their ability to be tuned, which arises from the large number of possible anion-cation pairs. Therefore it should be possible to obtain ILs with different physicochemical properties according to their molecular structure.

Concerning viscosity of ILs, it varies from low-viscosity fluids, similar to common organic solvents, to glasslike extremely viscous fluids [10-12]. This property depends strongly on the molecular structure and is highly dependent on the interactions between the ions: 
electrostatic, van der Waals interactions and hydrogen bonding [12-14]. Several authors have analyzed the effect of the structure on the viscosity and its temperature and pressure dependence [12,14-20]. However, due to the high variety of ions it is not possible to have the viscosity values for a broad number of ILs with a common ion in order to obtain a general trend for viscosity [12]. Some conclusions concerning the length and number of alkyl chains are that the longer the alkyl chain, the higher the viscosity, as was reported for imidazolium, pyridinium, alkylammonium and pyrrolidinium based ILs [21-23], and also that the higher the number of alkyl chains, the higher the viscosity $[16,24,25]$. Nevertheless, there are some exceptions to the first rule: some ILs with ethyl chains are less viscous with the corresponding ILs with methyl chains [12].

It is worth pointing out that viscosity values of ILs reported in literature show discrepancies higher than the uncertainty claimed by authors [26]. Although the water content and other impurities present in samples affect significantly viscosity values and other physical properties [27], the experimental techniques are sometimes not adequate to measure the viscosity, and many authors have recommended the use of primary viscosimetric techniques $[26,28]$ to get more reliable data. However due to the wide viscosity ranges and high electrical conductivities of ILs, it is not always possible to use primary devices, especially in broad temperature, pressure and viscosity ranges, and secondary ones have to be considered. Therefore the calibration of the devices has to be carried out carefully and as accurately as possible in order to minimize the contributions of the uncertainty in the viscosity measurements. Despite of the large amount of studies of viscosity of ILs at atmospheric pressure, the viscosity database of ILs at high pressure is still scarce [10,15,29-32].

In this work we have studied two ILs for which there are not available viscosity data at high pressures. These liquids are 1-butyl-1-methylpyrrolidinium tris(pentafluoroethyl)trifluorophosphate, $\quad\left[\mathrm{C}_{4} \mathrm{C}_{1} \mathrm{Pyrr}\right]\left[\left(\mathrm{C}_{2} \mathrm{~F}_{5}\right)_{3} \mathrm{PF}_{3}\right], \quad$ and 1-butyl-1methylpyrrolidinium trifluoromethanesulfonate, $\left[\mathrm{C}_{4} \mathrm{C}_{1} \mathrm{Pyrr}\right]\left[\mathrm{CF}_{3} \mathrm{SO}_{3}\right]$. The latter has shown significant friction reduction whereas $\left[\mathrm{C}_{4} \mathrm{C}_{1} \mathrm{Pyrr}\right]\left[\left(\mathrm{C}_{2} \mathrm{~F}_{5}\right)_{3} \mathrm{PF}_{3}\right]$ presents good anti-wear performance [33] for boundary lubrication. Besides, some $\left[\mathrm{CF}_{3} \mathrm{SO}_{3}\right]^{-}$based ILs have excellent values of thermal stability. In fact, $1 \%$ mass loss is obtained at isothermal conditions after 10 hours under air atmosphere at $483 \mathrm{~K}$ for $\left[\mathrm{C}_{4} \mathrm{C}_{1} \mathrm{Pyrr}\right]\left[\left(\mathrm{C}_{2} \mathrm{~F}_{5}\right)_{3} \mathrm{PF}_{3}\right]$ and at $521 \mathrm{~K}$ for 
$\left[\mathrm{C}_{4} \mathrm{C}_{1} \mathrm{Pyrr}\right]\left[\mathrm{CF}_{3} \mathrm{SO}_{3}\right]$ [2] whereas for polyalkylene glycol (PAG) or polyolester base lubricants the thermal stability is strongly lower [34].

The viscosities reported in this work were measured in a falling body viscometer at temperatures from $303.15 \mathrm{~K}$ to $353.15 \mathrm{~K}$ at pressures up to $150 \mathrm{MPa}$. This device was modified in order to achieve more accurate values. We also provide empirical correlations of the experimental viscosity values as a function of temperature and pressure, to perform an analysis on dependence on both properties and they suitability as lubricants under EHL. Moreover, the hard-sphere scheme and the thermodynamic scaling model, two theoretical methods that allow predicting viscosity as a function of temperature and density, are applied for the two ILs.

\section{Experimental}

\subsection{Materials}

Three Cannon certified viscosity oils, N75, N100 and S600, were used as calibration fluids whereas squalane (CAS 111-01-3) (Sigma-Aldrich) was used as verification fluid. The squalane sample presents a specified mole-fraction purity of $99 \%$ experimentally determined by gas chromatographic analysis. $\left[\mathrm{C}_{4} \mathrm{C}_{1} \mathrm{Pyrr}\right]\left[\mathrm{CF}_{3} \mathrm{SO}_{3}\right]$ and $\left[\mathrm{C}_{4} \mathrm{C}_{1} \mathrm{Pyrr}\right]\left[\left(\mathrm{C}_{2} \mathrm{~F}_{5}\right)_{3} \mathrm{PF}_{3}\right]$ samples were kindly provided by Merck KGaA and present mole-fraction purities higher than $98 \%$ and $99 \%$, respectively, both determined by electrophoresis. Full and short names, CAS number, molecular structures and purities are gathered in table 1.

Due to the fact that the water content has a strong effect on the viscosity of the ILs [27], before measurements, samples were treated under vacuum evaporation at room temperature with agitation by using a rotary pump Edwards RV3 to remove the water and volatile compounds during several days, the vacuum level $(<10 \mathrm{~Pa})$ was measured using a vacuometer Edwards Pirani 501. The water content of each IL was measured by coulometric Karl Fischer titration with a Mettler Toledo DL32 titrator. The water content expressed as weight fraction was (5 and 12) $10^{-6}$ for $\left[\mathrm{C}_{4} \mathrm{C}_{1} \mathrm{Pyrr}\right]\left[\left(\mathrm{C}_{2} \mathrm{~F}_{5}\right)_{3} \mathrm{PF}_{3}\right]$ and $\left[\mathrm{C}_{4} \mathrm{C}_{1} \mathrm{Pyrr}\right]\left[\mathrm{CF}_{3} \mathrm{SO}_{3}\right]$, respectively. Samples were transferred to the viscometer with a glass syringe and introduced through a Hamilton valve, $\mathrm{HV}$ Standard PTFE. 


\subsection{Measurement techniques}

Viscosities at high pressure were measured using a falling body viscometer, VisLPT1, which can operate at pressures up to $150 \mathrm{MPa}$. This device has been further described in previous articles [15,16,35]. Four new Pt100 temperature probes were installed around the inner tube instead of the thermocouple originally located. The expanded uncertainty of these thermometers was $\pm 0.1 \mathrm{~K}$. The liquid is compressed by means of a manual pressure generator HiP (model 50-5.75-30) and the pressure is measured by a transducer (HBM P3MB) and a numeric indicator (HBM Scout 55) with an expanded uncertainty of $\pm 0.2 \mathrm{MPa}$. The hemispherical sinker employed in this work is the same as that used in the previous works $[15,16,35]$. It is made of magnetic steel and it has a diameter of $6.10 \mathrm{~mm}$ and a length of $20 \mathrm{~mm}$.

The measuring principle of a falling body viscometer is based on the relationship between the fluid viscosity $(\eta)$ and the time $(\Delta t)$ that a solid takes to fall inside the inner tube through the fluid (once it has reached its terminal velocity under conditions of laminar flow) [36]. Laminar flow implies that the Reynolds number, $R e$, has to be low. To estimate $R e$, there are several criteria proposed by different authors [37-39]. Taking into account the Isdale et al. criterion [38], $R e$ can be estimated from the following equation:

$$
R e=\frac{2 r^{2}}{R-r} \frac{\rho \cdot v}{\eta}
$$

where $R$ and $r$ are the radius of the inner tube and the radius of the sinker, respectively, whereas $\rho$ and $\eta$ are the density and the viscosity of the fluid and $v$ is the velocity of the sinker (in this case, the distance between two consecutives coils divided by the time that the sinker spends in crossing it). The condition of laminar flow is observed when the Reynolds number is lower than 1000. For all the fluids studied in this work (N75, N100, S600, squalane and the two ILs) this number is much lower, as can be observed in figure 1.

The working equation employed in this work is:

$$
\eta(p, T)=\frac{t\left(1-\rho / \rho_{s}\right)}{A\left[1+2 \alpha_{v t}\left(T-T_{r e f}\right)\right]\left[1-2 \beta_{v t}\left(p-p_{r e f}\right) / 3\right]}
$$


where $t$ is the falling time, $\rho$ and $\rho_{s}$ are the density for the fluid and for the sinker, respectively, at the temperature $T$ and pressure $p$. The $A$ is a calibration constant, and $\alpha_{v t}$ and $\beta_{v t}$, are the coefficients of expansion and compressibility of the viscometer tube (INCONEL 718) at reference conditions $T_{\text {ref }}=298.15 \mathrm{~K}$ and $p_{\text {ref }}=0.1 \mathrm{MPa}$. This equation presents the advantage that the parameter $A$ is not dependent on either pressure or temperature; therefore the calibration procedure can be performed at atmospheric pressure with certificated standard oils. This type of equation has been successful used for similar viscometers to measure low and high viscous fluids, such as ionic liquids [19,20,40-43].

Density of the sinker for each $p$ and $T$ condition is calculated with the following equation:

$$
\rho_{s}(p, T)=\frac{\rho_{s}\left(p_{r e f}, T_{r e f}\right)}{\left[1+3 \alpha_{s}\left(T-T_{r e f}\right)\right]\left[1-\beta_{s}\left(p-p_{r e f}\right)\right]},
$$

where $\rho_{s}\left(p_{\text {ref }}, T_{\text {ref }}\right)=7.695 \mathrm{~g} \cdot \mathrm{cm}^{-3}$, whereas $\alpha_{\mathrm{s}}$ and $\beta_{\mathrm{s}}$ are the coefficients of expansion and compressibility of the sinker (X4CrNiMo16-5-1) at reference conditions $T_{\text {ref }}=298.15 \mathrm{~K}$ and $p_{\text {ref }}$ $=0.1 \mathrm{MPa}$. Values of the expansion coefficients are $\alpha_{\mathrm{s}}=10.8 \times 10^{-6} \mathrm{~K}^{-1}$ and $\alpha_{\mathrm{vt}}=12.8 \times 10^{-6} \mathrm{~K}^{-1}$, respectively, whereas for compressibility we have $\beta_{\mathrm{s}}=5 \times 10^{-6} \mathrm{MPa}^{-1}$ and $\beta_{\mathrm{vt}}=4.8 \times 10^{-6} \mathrm{MPa}^{-1}$. Calibration constant $A$ for equation (2) is estimated from viscosity reference fluids. We have performed the calibration procedure at atmospheric pressure from $29 \mathrm{~K} 3.15$ to $353.15 \mathrm{~K}$ with the three Cannon certified viscosity oils. These fluids cover the viscosity range from $14.5 \mathrm{mPa} \cdot \mathrm{s}$ for Cannon N75 up to $1482 \mathrm{mPa} \cdot \mathrm{s}$ for Cannon $\mathrm{S} 600$. The value of the calibration constant $A$ is (1.206 \pm 0.003$) \mathrm{Pa}^{-1}$. Taking into account uncertainties of temperature, pressure, falling times, calibration constant and densities of both sinker and fluid, the uncertainty of the device is estimated to be $\pm 3.5 \%$ with a coverage factor $k=2$.

To check the calibration procedure, a reference fluid with well-known viscosity as a function of pressure and temperature is needed. Unfortunately, there is a scarcity of literature data for reference fluids of moderate viscosity at high pressure. Diisodecyl phthalate, squalane, di(2-ethylhexyl) sebacate, 2-ethylhexylbenzoate and bis(2-ethylhexyl)phthalate are some of the fluids that have been proposed as candidates for viscosity reference fluids [44]. Among them, squalane has being recommended as a secondary reference material for viscometry at moderate 
to high pressure and for moderate viscous fluids [35]. Mylona et al. [45] have proposed two different correlations of the viscosity one as a function of density and temperature and the other as a function of pressure and temperature. The former is based on the Assael-Dymond model [46] and covers the temperature range from $320 \mathrm{~K}$ to $473 \mathrm{~K}$ at pressures to $200 \mathrm{MPa}$ with an average absolute deviation of $1.41 \%$, a bias of $-0.09 \%$, and an expanded uncertainty (at the $95 \%$ confidence level) of 3\%. The second correlation, based on a modified Vogel-Fulcher-Tammann equation, is valid from $278 \mathrm{~K}$ to $473 \mathrm{~K}$ at pressures to $200 \mathrm{MPa}$, and has an average absolute deviation of $1.69 \%$, a bias of $-0.04 \%$, and an expanded uncertainty (at the $95 \%$ confidence level) of $4.75 \%$. Moreover, density values of squalane are needed in equation (2) to determine the experimental viscosity and to apply the correlation based in the Assael-Dymond model. Mylona et al. [45] also provides a correlation for density valid from $273 \mathrm{~K}$ to $473 \mathrm{~K}$ and up to $200 \mathrm{MPa}$. We have measured the falling times for squalane from $303.15 \mathrm{~K}$ to $353.15 \mathrm{~K}$ at pressures up to $150 \mathrm{MPa}$ and compared our viscosity values (table S1 of the supplementary information) with those provided by the two proposed correlations. Comparisons with values calculated with the Mylona et al. [45] correlation based on Assael-Dymond model present an average absolute deviation $(\mathrm{AAD})$ of $0.9 \%$ and a maximum deviation $(\mathrm{MaxD})$ of $2.1 \%$, whereas comparisons with the correlation based on the modified Vogel-Fulcher-Tammann yield an AAD of $1.8 \%$ and a MaxD of 2.1\%. Figure 2 shows the deviations obtained using both Mylona et al. [45] correlations.

Viscosity measurements of both ILs studied in this work, $\left[\mathrm{C}_{4} \mathrm{C}_{1} \mathrm{Pyrr}\right]\left[\left(\mathrm{C}_{2} \mathrm{~F}_{5}\right)_{3} \mathrm{PF}_{3}\right]$ and $\left[\mathrm{C}_{4} \mathrm{C}_{1} \mathrm{Pyrr}\right]\left[\mathrm{CF}_{3} \mathrm{SO}_{3}\right]$, were carried out at six different isotherms $(303.15,313.15,323.15,333.15$, 343.15 and 353.15$) \mathrm{K}$ and at pressures up to $150 \mathrm{MPa}$. Density values for these ILs were obtained through the Tammann-Tait correlation obtained from values of experimental densities measured with a vibrating tube densimeter from $T=(278.15$ to 398.15$) \mathrm{K}$ and up to $120 \mathrm{MPa}$ $[47,48]$. For pressures higher than $120 \mathrm{MPa}$ up to $150 \mathrm{MPa}$, an extrapolation of the density was performed. As has been previously demonstrated, this fact does not affect significantly the values of the viscosity at high pressure $[15,16]$.

In 2007 Kulkarni et al. [49] have found seven ILs with Non-Newtonian behaviour, subsequently other authors as Wang et al. [50,51] have found other non-Newtonian ILs that exhibit non-Newtonian behaviour. All these rheological experiments were performed at 
atmospheric pressure. In order to check the Newtonian behaviour of the two ILs studied in this work at some pressures and temperatures, we have used a rheometer that had been recently implemented in our laboratory. This device is based on a Reologica StressTech HTHP which consists of a DIN53019 concentric cylinder measurement and relies on Couette flow. The sample under study is confined between a stationary cup and a rotating bob with a $1 \mathrm{~mm}$ gap. The inner cylinder has a diameter of $25 \mathrm{~mm}$ and is suspended by magnetic coupling and rotates on low friction air bearing. The rheometer can operate at shear rate between (20-1000) $\mathrm{s}^{-1}$, for torque from $\left(1 \times 10^{-4}\right.$ to $\left.4 \times 10^{-2}\right) \mathrm{N} \cdot \mathrm{m}$ and at shear stress up to $350 \mathrm{~Pa}$. Currently, this device operates from $298.15 \mathrm{~K}$ to $353.15 \mathrm{~K}$ and at pressures up to $75 \mathrm{MPa}$. The temperature is controlled by means of an electrical resistance heating and a thermostatic bath, whereas the pressure is set by means of a HiP manual syringe pump. We have estimated that viscosity measurements of this device present an uncertainty of $10 \%$. Reliability of this device has been checked by using a PAO40 and Polybutene $\mathrm{H} 8$ oils [52]. Further details of the device can be found in the following reference[53].

\section{Results and discussion}

The viscosities at high pressures for $\left[\mathrm{C}_{4} \mathrm{C}_{1} \mathrm{Pyrr}\right]\left[\left(\mathrm{C}_{2} \mathrm{~F}_{5}\right)_{3} \mathrm{PF}_{3}\right]$ and $\left[\mathrm{C}_{4} \mathrm{C}_{1} \mathrm{Pyrr}\right]\left[\mathrm{CF}_{3} \mathrm{SO}_{3}\right]$ are presented in table 2 and range from (24.7 to 3485) $\mathrm{mPa} \cdot \mathrm{s}$ and (22.5 to 738) $\mathrm{mPa} \cdot \mathrm{s}$, respectively. These values are plotted in figure 3 , where it can observed that at the same conditions of pressure and temperature, the IL with $\left[\mathrm{CF}_{3} \mathrm{SO}_{3}\right]^{-}$anion is less viscous than the one with the $\left[\left(\mathrm{C}_{2} \mathrm{~F}_{5}\right)_{3} \mathrm{PF}_{3}\right]^{-}$. At atmospheric pressure, this trend had been previously reported [13]. Furthermore, the effect of pressure on viscosity of both liquids is very different. The IL with the $\left[\left(\mathrm{C}_{2} \mathrm{~F}_{5}\right)_{3} \mathrm{PF}_{3}\right]^{-}$anion is much more sensitive to pressure changes than the one with $\left[\mathrm{CF}_{3} \mathrm{SO}_{3}\right]^{-}$. Thus, at $303.15 \mathrm{~K}$ an increment on the pressure from $10 \mathrm{MPa}$ to $150 \mathrm{MPa}$ leads to a viscosity increment of $1700 \%$ for $\left[\mathrm{C}_{4} \mathrm{C}_{1} \mathrm{Pyrr}\right]\left[\left(\mathrm{C}_{2} \mathrm{~F}_{5}\right)_{3} \mathrm{PF}_{3}\right]$ whereas $400 \%$ of increase is found for $\left[\mathrm{C}_{4} \mathrm{C}_{1} \mathrm{Pyrr}\right]\left[\mathrm{CF}_{3} \mathrm{SO}_{3}\right]$. These differences become smaller as temperature increases.

The rheological tests were carried out for the two ILs from $303.15 \mathrm{~K}$ to $353.15 \mathrm{~K}$ and at pressures up to $75 \mathrm{MPa}$. Results show Newtonian behaviour over the whole measurement range. In figure 4 is shown, as an example, the flow curves for both ILs at $T=303.15 \mathrm{~K}$. Their flow curves present linear dependence of the stress $(\sigma)$ with the shear rate $(\gamma)$.Viscosity data obtained with this rheometer for both ILs are reported in table S2 of the supplementary information. 
Besides, viscosity values higher than $100 \mathrm{mPa} \cdot \mathrm{s}$ obtained with both the rheometer and falling body viscometer show an absolute average deviation of $5.4 \%$ and $4.4 \%$ for $\left[\mathrm{C}_{4} \mathrm{C}_{1} \mathrm{Pyrr}\right]\left[\left(\mathrm{C}_{2} \mathrm{~F}_{5}\right)_{3} \mathrm{PF}_{3}\right]$ and $\left[\mathrm{C}_{4} \mathrm{C}_{1} \mathrm{Pyrr}\right]\left[\mathrm{CF}_{3} \mathrm{SO}_{3}\right]$, respectively. The maximum deviation (11\% for $\left[\mathrm{C}_{4} \mathrm{C}_{1} \mathrm{Pyrr}\right]\left[\left(\mathrm{C}_{2} \mathrm{~F}_{5}\right)_{3} \mathrm{PF}_{3}\right]$ at $313.15 \mathrm{~K}$ and $\left.75 \mathrm{MPa}\right)$ is within the combined uncertainty of both devices.

In addition to the viscosities at high pressure obtained with the falling body viscometer (table 2) for ILs, in a previous work we published their viscosities at atmospheric pressure [13]. These measurements had been carried out with a rotational viscometer Anton Paar Stabinger SVM3000 from $T=(283.15$ to 373.15$) \mathrm{K}$ with an uncertainty of $\pm 1 \%$. Viscosity values obtained with both devices are fitted together to four different equations as a function of pressure and temperature. These fitting equations are as follows:

$$
\eta(p, T)=A \exp \left(\frac{B}{T-C}\right)\left(\frac{p+E(T)}{p_{r e f}+E(T)}\right)^{D}
$$

where $A, B$ and $C$ are obtained fitting viscosity values at the reference pressure $(0.1 \mathrm{MPa})$ as a function of temperature, and $\mathrm{E}(\mathrm{T})$ is a second-degree polynomial $E(T)=E_{0}+E_{1} T+E_{2} T^{2}$. Equation (4), proposed by Comuñas et al. [54], is a modified Vogel-Fulcher-Tammann equation as well as the following two equations, which were proposed by Harris et al. [31].

$$
\begin{aligned}
& \eta(p, T)=\exp \left(a+b p+\frac{c+d p+e p^{2}}{T-T_{0}}\right) \\
& \eta(p, T)=\exp \left(a+b p+c \frac{T_{0}(p)}{T-T_{0}(p)}\right)
\end{aligned}
$$

where $T_{0}(p)=d+e \cdot p+f \cdot p^{2}$.

The last expression is a modified Litovitz equation given by: 
$\eta(p, T)=\exp \left(a+b p+\frac{c+d p+e p^{2}}{T^{3}}\right)$

The values of the parameters of equations (4)-(7) are gathered in table 3 . These equations lead to good correlations of the experimental values in all cases with AADs lower than $2 \%$. To study the pressure and temperature effect on viscosity, the pressure-viscosity and temperature-viscosity coefficients are analyzed. These two parameters are important to characterize lubricants and can be calculated by differentiation as follows:

$$
\begin{aligned}
& \alpha(p)=\frac{1}{\eta(p, T)}\left(\frac{\partial \eta(p, T)}{\partial p}\right)_{T} \\
& \beta(T)=-\frac{1}{\eta(p, T)}\left(\frac{\partial \eta(p, T)}{\partial T}\right)_{p}
\end{aligned}
$$

Using equation (4) both coefficients can be expressed as:

$$
\begin{aligned}
& \alpha(p)=\frac{D}{E(T)+p} \\
& \beta(T)=\frac{B}{(T-C)^{2}}+D \frac{E^{\prime}(T) \cdot(p-0.1)}{(0.1-E(T))(p+E(T))}
\end{aligned}
$$

where $E^{\prime}(T)=E_{1}+2 E_{2} T$ is the derivative of $E(T)$.

As can be seen in table 4 and figure 5, $\alpha(p)$ values are higher for $\left[\mathrm{C}_{4} \mathrm{C}_{1} \mathrm{Pyrr}\right]\left[\left(\mathrm{C}_{2} \mathrm{~F}_{5}\right)_{3} \mathrm{PF}_{3}\right]$ and are almost pressure independent (Barus behaviour). Usually the pressure-viscosity depends more strongly with the pressure but we have also found $\alpha(p)$ values for $\left[\mathrm{C}_{4} \mathrm{C}_{1} \mathrm{C}_{1} \mathrm{Im}\right]\left[\left(\mathrm{C}_{2} \mathrm{~F}_{5}\right)_{3} \mathrm{PF}_{3}\right]$ are pressure independent. We have previously found that other two ILs based on $\left[\left(\mathrm{C}_{2} \mathrm{~F}_{5}\right)_{3} \mathrm{PF}_{3}\right]^{-}$ anion present higher $\alpha(p)$ values than other four ILs and their values are similar to those of squalane and propylene glycol dimethyl ethers [16]. Comparing the $\alpha(p)$ for other $\left[\mathrm{C}_{4} \mathrm{C}_{1} \mathrm{Pyrr}\right]^{+}$ based ILs $[15,16]$, the following trend is obtained: $\left[\left(\mathrm{C}_{2} \mathrm{~F}_{5}\right)_{3} \mathrm{PF}_{3}\right]^{-}>\left[\mathrm{NTf}_{2}\right]^{-}>\left[\mathrm{CF}_{3} \mathrm{SO}_{3}\right]^{-}$, at least at pressures up to $90 \mathrm{MPa}$. Thus, it seems that a higher number of fluorine atoms leads to a higher 
$\alpha(p)$ value. A comparison of the pressure-viscosity coefficients of $\left[\mathrm{C}_{4} \mathrm{C}_{1} \mathrm{Pyrr}\right]\left[\left(\mathrm{C}_{2} \mathrm{~F}_{5}\right)_{3} \mathrm{PF}_{3}\right]$ and $\left[\mathrm{C}_{1} \mathrm{OC}_{2} \mathrm{C}_{1} \mathrm{Pyrr}\right]\left[\left(\mathrm{C}_{2} \mathrm{~F}_{5}\right)_{3} \mathrm{PF}_{3}\right]$ ILs shows that $\alpha(p)$ decreases when we replace a methylene group of the alkyl chain for an oxygen atom as we had previously reported for [NTf $]^{-}$ILs [15]. On the other hand, as can be seen in figure 6 the temperature effect on the viscosity is higher for the $\left[\left(\mathrm{C}_{2} \mathrm{~F}_{5}\right)_{3} \mathrm{PF}_{3}\right]^{-}$based IL than for the $\left[\mathrm{CF}_{3} \mathrm{SO}_{3}\right]^{-} \mathrm{IL}$, especially at high pressure. This fact is in agreement with the results that we have reported previously concerning viscosity index (VI) $[13,14]$. Thus, $\left[\left(\mathrm{C}_{2} \mathrm{~F}_{5}\right)_{3} \mathrm{PF}_{3}\right]^{-}$based ILs presents worse (higher) VI values than other ILs based on $\left[\mathrm{CF}_{3} \mathrm{SO}_{3}\right]^{-}$or $\left[\mathrm{NTf}_{2}\right]^{-}$anions. Therefore $\left[\left(\mathrm{C}_{2} \mathrm{~F}_{5}\right)_{3} \mathrm{PF}_{3}\right]^{-}$based ILs should not be the most suitable in lubrication applications where temperature changes happen.

According the American Gear Manufacturers Association under the elastohydrodynamic regime of lubrication, when geometry, elastic properties, speed and load are fixed, the central film thickness is a function of the pressure-viscosity coefficient $(\alpha)$ and the absolute viscosity $\left(\eta_{0}\right)$ by means of the expression [55]:

$h_{\text {cent }} /(\mu m) \propto\left(\eta_{0} / m P a \cdot s\right)^{0.69}\left(\alpha / G P a^{-1}\right)^{0.56}$

According to Bair et al. [56] the universal pressure-viscosity coefficient can be estimated with the following expression:

$\alpha=\alpha_{f i l m}=\frac{1-\exp (-3)}{p_{i v}\left(3 / \alpha^{*}\right)}$,

where $\mathrm{p}_{\mathrm{iv}}$ the isoviscous pressure given by:

$p_{i v}=\int_{0}^{\urcorner p} \frac{\eta\left(p^{\prime}=0\right) d p^{\prime}}{\eta\left(p^{\prime}\right)}$

and $\alpha^{*}$ is the reciprocal asymptotic isoviscous pressure.

$\alpha^{*}=\frac{1}{p_{i v}(\infty)}=\left[\int_{0}^{\infty} \frac{\eta(p=0) d p}{\eta(p)}\right]^{-1}$ 
High values of film thickness are desired when boundary wear has to be avoided, whereas low values are also needed to save friction energy, reduce subsurface stress and also pressure peaks. In table 5 the universal pressure-viscosity coefficient, the reciprocal asymptotic isoviscous pressure and the product $\eta_{0}^{0.69} \alpha_{\text {film }}^{0.56}$ are gathered for the two ILs at several temperatures. The values obtained of the reciprocal asymptotic isoviscous pressure coefficient, $\alpha^{*}$, are slightly lower than those of $\alpha_{\text {film }}$ for both ILs. In general, the use of $\alpha^{*}$ tends to underestimate the film thickness [14,57]. The universal pressure-viscosity coefficient is much higher for the $\left[\left(\mathrm{C}_{2} \mathrm{~F}_{5}\right)_{3} \mathrm{PF}_{3}\right]^{-}$based IL than for the $\left[\mathrm{CF}_{3} \mathrm{SO}_{3}\right]^{-} \mathrm{IL}$. In fact, $\left[\left(\mathrm{C}_{2} \mathrm{~F}_{5}\right)_{3} \mathrm{PF}_{3}\right]^{-}$ILs present similar values to other synthetic oils as squalane or pentaerythritol tetra-2-ethylhexanoate [58]. The product $\eta_{0}^{0.69} \alpha_{\text {film }}^{0.56}$ is directly proportional to the $h_{\text {cent }}$ under the same conditions of operation (surface geometry and relative speed of the gear surfaces $U$ ). As can be seen in figure 7 , this product is higher for $\left[\mathrm{C}_{4} \mathrm{C}_{1} \mathrm{Pyrr}\right]\left[\left(\mathrm{C}_{2} \mathrm{~F}_{5}\right)_{3} \mathrm{PF}_{3}\right]$ as we expected (its viscosity and $\alpha$ values are higher). The difference between the $\eta_{0}^{0.69} \alpha_{\text {film }}^{0.56}$ values for both ILs diminishes as the temperature increases, being the value for $\left[\mathrm{C}_{4} \mathrm{C}_{1} \mathrm{Pyrr}\right]\left[\left(\mathrm{C}_{2} \mathrm{~F}_{5}\right)_{3} \mathrm{PF}_{3}\right]$ with respect to that of $\left[\mathrm{C}_{4} \mathrm{C}_{1} \mathrm{Pyrr}\right]\left[\mathrm{CF}_{3} \mathrm{SO}_{3}\right]$ around $60 \%$ and $35 \%$ higher at $303.15 \mathrm{~K}$ and $353.15 \mathrm{~K}$, respectively.

To model and calculate the viscosity of dense fluids several approaches have been developed, such as the hard-sphere scheme, the scaling thermodynamic or the friction theory model [59]. The scaling thermodynamic postulates that for a given liquid, properties such as viscosity, diffusion coefficient, electrical conductivity or structural relaxation time can be expressed solely as a function of the variable $T v^{\gamma}[60,61]$ :

$$
X(T, V)=f\left(T v^{\gamma}\right)=f\left(T \rho^{-\gamma}\right)
$$

whereas $X$ is a given liquid dynamic property, $v$ the specific volume and $\gamma$ the scaling coefficient, which quantifies the dependence of the dynamic property on volume in comparison to that on the temperature. The higher the $\gamma$ value, the stronger dependence on density of the transport property of the fluid [62]. Furthermore, when $\gamma$ is close to 0 it is assumed that the dynamics are controlled by the temperature $[60,62-64]$. This parameter reflects the repulsive interactions as well as the contributions from internal molecular modes, and attractive intermolecular forces for complex molecules or ions $[16,61]$. Pensado et al. [60] proposed the following expression for viscosity: 
$\eta(T, \rho)=\eta_{0} \exp \left[\left(\frac{A}{T v^{\gamma}}\right)^{\phi}\right]$

where $\eta_{0}, A, \gamma$ and $\phi$ may be used as fit parameters. This expression is based in another equation previously proposed by Casalini and Roland [65] for relaxation time of glass-forming liquids. For the two ILs studied in this work parameters of eq. (17) were obtained by fitting the viscosity as a function of temperature and specific volumes. To determine the latter, we have employed the density data from $[47,48]$. The values of the characteristic parameters of eq. (17) are presented in table 6, as well as the AAD\% between experimental and correlated values for each IL. The $\gamma$ value for $\left[\mathrm{C}_{4} \mathrm{C}_{1} \mathrm{Pyrr}\right]\left[\left(\mathrm{C}_{2} \mathrm{~F}_{5}\right)_{3} \mathrm{PF}_{3}\right](4.32)$ is higher than the one for $\left[\mathrm{C}_{4} \mathrm{C}_{1} \mathrm{Pyrr}\right]\left[\mathrm{CF}_{3} \mathrm{SO}_{3}\right]$ (3.17). Taken also into account that in a previous work we have found for $\left.\left[\mathrm{C}_{4} \mathrm{C}_{1} \mathrm{C}_{1} \operatorname{Im}\right]\left[\left(\mathrm{C}_{2} \mathrm{~F}_{5}\right)_{3} \mathrm{PF}_{3}\right)\right]$ and $\left[\mathrm{C}_{1} \mathrm{OC}_{2} \mathrm{C}_{1} \mathrm{Pyrr}\right]\left[\left(\mathrm{C}_{2} \mathrm{~F}_{5}\right)_{3} \mathrm{PF}_{3}\right] \gamma$ values higher than those of their corresponding $\left[\mathrm{NTf}_{2}\right]^{-}$ILs, it can be concluded that the role of the temperature on viscosity is less important for ILs based on $\left[\left(\mathrm{C}_{2} \mathrm{~F}_{5}\right)_{3} \mathrm{PF}_{3}\right]^{-}$anion than for other ILs [16]. The value for $\left[\mathrm{C}_{4} \mathrm{C}_{1}\right.$ Pyrr $]\left[\mathrm{CF}_{3} \mathrm{SO}_{3}\right](\gamma=3.17)$ is almost the same than the value for $\left[\mathrm{C}_{4} \mathrm{C}_{1}\right.$ Pyrr $]\left[\mathrm{NTf}_{2}\right](\gamma=3.16)$ [16]. In figure 8 viscosity of $\left[\mathrm{C}_{4} \mathrm{C}_{1} \mathrm{Pyrr}\right]\left[\left(\mathrm{C}_{2} \mathrm{~F}_{5}\right)_{3} \mathrm{PF}_{3}\right]$ versus density is depicted. When the viscosities of both ILs are plotted as a function of $\rho^{\gamma} \cdot T^{1}$ data collapse onto a single master curve for each fluid, as shows figure 9.

The hard-sphere scheme, developed by Assael and Dymond, is based on the Enskog hardsphere theory $[46,66-70]$. This powerful scheme allowed the correlation and prediction of the thermal conductivity and viscosity of a wide range of simple molecules, alkanes, aromatic hydrocarbons, alcohol as well as mixtures of liquids in an homologous series over a wide range of temperatures and pressures with a relative uncertainty of 5\% [71]. To apply the hard-sphere scheme it is convenient to consider reduced viscosity that is defined as follows:

$\eta^{*}=\frac{16}{5}\left(2 N_{A}\right)^{1 / 3} \pi^{1 / 2}\left(\frac{1}{M R T}\right)^{1 / 2} \frac{\eta V^{2 / 3}}{R_{\eta}}$

where $N_{A}$ is the Avogadro constant, $R$ the universal gas constant, $M$ the molecular mass, $V$ the molar volume and $R_{\eta}$ the roughness factor that has into account the non-spherical shape of the molecules of fluid. According to the hard-sphere theory the values for the reduced viscosities can 
be calculated for different reduced volumes, $\mathrm{V}_{\mathrm{r}}=\mathrm{V} / \mathrm{V}_{0}[46]$, where $V_{0}$, the characteristic molar volume $\left(\mathrm{m}^{3} / \mathrm{mol}\right)$ of the fluid, was considered as a polynomial function:

$$
V_{0}=\sum_{i=0}^{2} d_{i} T^{i}
$$

The reduced viscosity obeys the following dependence of the reduced volume [46]:

$$
\log \eta^{*}=\sum_{i=1}^{7} a_{\eta i}\left(\frac{V}{V_{0}}\right)^{-i}
$$

Taking into account equations (18) and (20), the viscosity values according the hard-spheres scheme can be obtained through the following expression:

$$
\log \eta=\log R_{\eta}+\sum_{i=0}^{7} a_{\eta i}\left(\frac{V_{0}(T)}{V}\right)^{i}-\log \left[\frac{16 \sqrt{\pi}}{5}\left(2 N_{A}\right)^{1 / 3}\right]-\frac{2}{3} \log V-\log \frac{1}{\sqrt{T}}
$$

The parameters $a_{\eta \mathrm{i}}$ were initially determined by Assael et al. [66] taking into account viscosity values for dense monatomic gases in the range $1.5<V_{r}<5$. However, this initial curve does not fit well values of high viscosity and dense fluids because their characteristics are outside the $V_{r}$ range. For these kind of fluids, a new universal reference function was recently proposed by Ciotta from a large database of experimental viscosities for alkanes extending up to reduced densities of 0.84 [71].

Recently, we have successfully applied this universal reference function to several ILs at pressures up to $40 \mathrm{MPa}$ [72] by taking into account a database of density, viscosity and thermal conductivity for 19 ILs. Average absolute deviations around 2\% for viscosity and $3 \%$ for thermal conductivity were obtained.

In the present work, for each IL we have used the viscosities reported in table 2, the densities previously measured in our laboratory [47,48] for pressures up to $40 \mathrm{MPa}$, together with the viscosities at $0.1 \mathrm{MPa}$ [13], to determine the parameters $d_{i}$ of the characteristic molar volume (eq. (19)) as well as the parameter $R_{\eta}$ (eq. (21)). For each fluid, the parameters are gathered in table 7 as well as the AAD between experimental and correlated values. As can be observed in 
figure 10, reduced viscosity values fit very well to the universal Ciotta curve $[71,73]$, even the high viscosities (those whose reduced volume is lower than 1.2). Deviations between experimental values and values obtained from the fit present $\mathrm{AAD} \%$ of $2.0 \%$ and $1.7 \%$ for $\left[\mathrm{C}_{4} \mathrm{C}_{1} \mathrm{Pyrr}\right]\left[\left(\mathrm{C}_{2} \mathrm{~F}_{5}\right)_{3} \mathrm{PF}_{3}\right]$ and $\left[\mathrm{C}_{4} \mathrm{C}_{1} \mathrm{Pyrr}\right]\left[\mathrm{CF}_{3} \mathrm{SO}_{3}\right]$, respectively. It is worth pointing out that the high values of reduced viscosity for ILs (figure 10) are extremely higher (up to 14000 for $\left.\left[\mathrm{C}_{4} \mathrm{C}_{1} \mathrm{Pyrr}\right]\left[\left(\mathrm{C}_{2} \mathrm{~F}_{5}\right)_{3} \mathrm{PF}_{3}\right]\right)$ than the reduced values for the original model [46] (below 50 for $\mathrm{Ne}$, $\mathrm{Ar}, \mathrm{Kr}$ and $\mathrm{Xe}$ ). This result was previously observed for other fluids and ILs [72] and shows the ability of the model to be extended outside their limits.

\section{Conclusions}

The viscosity behaviour of $\left[\mathrm{C}_{4} \mathrm{C}_{1} \mathrm{Pyrr}\right]\left[\left(\mathrm{C}_{2} \mathrm{~F}_{5}\right)_{3} \mathrm{PF}_{3}\right]$ and $\left[\mathrm{C}_{4} \mathrm{C}_{1} \mathrm{Pyrr}\right]\left[\mathrm{CF}_{3} \mathrm{SO}_{3}\right]$ was analyzed as a function of pressure and temperature, and their Newtonian behaviour was verified at pressures up to $75 \mathrm{MPa}$ and shear rate up to $1000 \mathrm{~s}^{-1}$. The $\alpha(p)$ values of $\left[\mathrm{C}_{4} \mathrm{C}_{1} \mathrm{Pyrr}\right]\left[\left(\mathrm{C}_{2} \mathrm{~F}_{5}\right)_{3} \mathrm{PF}_{3}\right]$ are almost pressure independent, and their values higher than those of $\left[\mathrm{C}_{4} \mathrm{C}_{1} \mathrm{Pyrr}\right]\left[\mathrm{CF}_{3} \mathrm{SO}_{3}\right]$. By comparison of $\alpha(p)$ for several $\left[\mathrm{C}_{4} \mathrm{C}_{1} \mathrm{Pyrr}\right]^{+}$based ILs the following trend of $\alpha(p)$ was found: $\left[\left(\mathrm{C}_{2} \mathrm{~F}_{5}\right)_{3} \mathrm{PF}_{3}\right]^{-}>\left[\mathrm{NTf}_{2}\right]^{-}>\left[\mathrm{CF}_{3} \mathrm{SO}_{3}\right]^{-}$. On the other hand, the temperature effect on the viscosity is higher for $\left[\mathrm{C}_{4} \mathrm{C}_{1} \mathrm{Pyrr}\right]\left[\left(\mathrm{C}_{2} \mathrm{~F}_{5}\right)_{3} \mathrm{PF}_{3}\right]$ than for the $\left[\mathrm{C}_{4} \mathrm{C}_{1} \mathrm{Pyrr}\right]\left[\mathrm{CF}_{3} \mathrm{SO}_{3}\right]$. The viscosity-pressure behaviour of $\left[\mathrm{C}_{4} \mathrm{C}_{1} \mathrm{Pyrr}\right]\left[\left(\mathrm{C}_{2} \mathrm{~F}_{5}\right)_{3} \mathrm{PF}_{3}\right]$ makes it a potential candidate as lubricant, in fact their universal pressure-viscosity coefficient values are similar to those of synthetic oils as squalane or pentaerythritol tetra-2-ethylhexanoate. Moreover, under EHL, its film thickness is greater than that of $\left[\mathrm{C}_{4} \mathrm{C}_{1} \mathrm{Pyrr}\right]\left[\mathrm{CF}_{3} \mathrm{SO}_{3}\right]$, for the same operation conditions. Finally, the scaling thermodynamic approach and the hard-spheres scheme have been successfully applied, which allow us to provide two fundamental based correlations of the viscosity as a function of the density and the temperature. The first model fits the experimental results with an $\mathrm{AAD}$ lower than $2 \%$ for both fluids up to $150 \mathrm{MPa}$, using four parameters whereas the hard-sphere scheme correlates the viscosity values up to $40 \mathrm{MPa}$ with an AAD of $2 \%$ for $\left[\mathrm{C}_{4} \mathrm{C}_{1} \mathrm{Pyrr}\right]\left[\left(\mathrm{C}_{2} \mathrm{~F}_{5}\right)_{3} \mathrm{PF}_{3}\right]$ and $1.7 \%$ for $\left[\mathrm{C}_{4} \mathrm{C}_{1} \mathrm{Pyrr}\right]\left[\mathrm{CF}_{3} \mathrm{SO}_{3}\right]$ also with four parameters.

\section{Acknowledgements}


This work was supported by Spanish Ministry of Science and Innovation and EU FEDER Program through the CTQ2011-23925 project. Authors acknowledge to Merck KGaA for providing us the samples of ILs

\section{References}

[1] T. Mang, Lubricants in the Triological System. in: T. Mang, W. Dresel, (Eds.), Lubricants and Lubrication, Wiley-VCH, Germany, 2001, pp. 7-20.

[2] M.-D. Bermúdez, A.-E. Jiménez, J. Sanes, F.-J. Carrión, Mol. 14 (2009) 2888-2908.

[3] D. Zhu, Q. Jane Wang, J. Tribol. 133 (2011) 041001.

[4] C. Ye, W. Liu, Y. Chen, L. Yu, Chem. Commun. (2001) 2244-2245.

[5] A.E. Somers, P.C. Howlett, D.R. MacFarlane, M. Forsyth, Lubricants 1 (2013) 3-21.

[6] H. Li, M.W. Rutland, R. Atkin, Phys. Chem. Chem. Phys. 15 (2013) 14616-14623.

[7] M. Palacio, B. Bhushan, Tribol Lett 40 (2010) 247-268.

[8] V. Pejaković, M. Kronberger, M. Mahrova, M. Vilas, E. Tojo, M. Kalin, Proceedings of the Institution of Mechanical Engineers, Part J: Journal of Engineering Tribology 226 (2012) 923-932.

[9] I. Otero, E.R. López, M. Reichelt, J. Fernández, Tribol. Int. 70 (2014) 104-111.

[10] M. Atilhan, J. Jacquemin, D. Rooney, M. Khraisheh, S. Aparicio, Ind. Eng. Chem. Res. 52 (2013) 16774-16785.

[11] D. Rooney, J. Jacquemin, R. Gardas, Thermophysical Properties of Ionic Liquids. in: B. Kirchner, (Ed.), Ionic Liquids, Springer Berlin Heidelberg, 2010, pp. 185-212.

[12] J. Fernández, F.M. Gaciño, Properties and Green Aspects of Ionic Liquids. in: A.P. de los Rios, F.J. Hernández-Fernández, (Eds.), Ionic Liquids in Separation Technology, Elsevier, 2014, pp. 3-12.

[13] F.M. Gaciño, T. Regueira, L. Lugo, M.J.P. Comuñas, J. Fernández, J. Chem. Eng. Data 56 (2011) 4984-4999.

[14] A.S. Pensado, M.J.P. Comuñas, J. Fernández, Tribol Lett 31 (2008) 107-118.

[15] F.M. Gaciño, X. Paredes, M.J.P. Comuñas, J. Fernández, J. Chem. Thermodyn. 54 (2012) 302-309.

[16] M.J.P. Comuñas, X. Paredes, F.M. Gaciño, J. Fernández, J.P. Bazile, C. Boned, J.L. Daridon, G. Galliero, J. Pauly, K.R. Harris, M.J. Assael, S.K. Mylona, J. Phys. Chem. Ref. Data 42 (2013).

[17] G. Yu, D. Zhao, L. Wen, S. Yang, X. Chen, AICHE J. 58 (2012) 2885-2899.

[18] S. Zhang, N. Sun, X. He, X. Lu, X. Zhang, J. Phys. Chem. Ref. Data 35 (2006) 14751517.

[19] K.R. Harris, M. Kanakubo, L.A. Woolf, J. Chem. Eng. Data 52 (2007) 1080-1085.

[20] K.R. Harris, L.A. Woolf, M. Kanakubo, J. Chem. Eng. Data 50 (2005) 1777-1782.

[21] Y. Yoshida, O. Baba, G. Saito, J. Phys. Chem. B 111 (2007) 4742-4749.

[22] T.L. Greaves, C.J. Drummond, Chem. Rev. 108 (2008) 206-237.

[23] L.G. Sánchez, J.R. Espel, F. Onink, G.W. Meindersma, A.B. de Haan, J. Chem. Eng. Data 54 (2009) 2803-2812.

[24] K. Fumino, A. Wulf, R. Ludwig, Angew. Chem. Int. Ed. 47 (2008) 8731-8734.

[25] K. Fumino, A. Wulf, R. Ludwig, Angew. Chem. Int. Ed. 47 (2008) 3830-3834.

[26] J.F. Diogo, F.P. Caetano, J.N.A. Fareleira, W. Wakeham, Int J Thermophys (2013) 1-21. 
[27] P.J. Carvalho, T. Regueira, L.M.N.B.F. Santos, J. Fernández, J.A.P. Coutinho, J. Chem. Eng. Data 55 (2009) 645-652.

[28] C.A. Nieto de Castro, F.J.V. Santos, J.M.N.A. Fareleira, W.A. Wakeham, J. Chem. Eng. Data 54 (2008) 171-178.

[29] S. Aparicio, M. Atilhan, F. Karadas, Ind. Eng. Chem. Res. 49 (2010) 9580-9595.

[30] I. Bandrés, R. Alcalde, C. Lafuente, M. Atilhan, S. Aparicio, The Journal of Physical Chemistry B 115 (2011) 12499-12513.

[31] K.R. Harris, L.A. Woolf, M. Kanakubo, T. Rüther, J. Chem. Eng. Data 56 (2011) 46724685.

[32] F.M. Gaciño, X. Paredes, M.J.P. Comuñas, J. Fernández, J. Chem. Thermodyn. 62 (2013) 162-169.

[33] I. Otero, E.R. López, M. Reichelt, J. Fernández, Tribol. Int. 77 (2014) 160-170.

[34] J. Salgado, M. Villanueva, J.J. Parajó, J. Fernández, Long-term thermal stability of ionic liquids and other synthetic lubricant bases, LUBMAT, Bilbao, Spain, 2012.

[35] M.J.P. Comuñas, X. Paredes, F.M. Gaciño, J. Fernández, J.-P. Bazile, C. Boned, J.-L. Daridon, G. Galliero, J. Pauly, K.R. Harris, J. Chem. Thermodyn. 69 (2014) 201-208.

[36] J. Kestin, W.A. Wakeham, Transport properties of fluids: Thermal conductivity, viscosity and diffusion coefficient, Purdue Research Foundation, New York, 1988.

[37] M.C.S. Chen, J.A. Lescarboura, G.W. Swift, AICHE J. 14 (1968) 123-127.

[38] J.D. Isdale, J.H. Dymond, T.A. Brawn, High Temp.-High Press, 11 (1979) 571-580.

[39] J. Lohrenz, F. Kurata, AICHE J. 8 (1962) 190-193.

[40] R. Malhotra, W.E. Price, L.A. Woolf, A.J. Easteal, Int J Thermophys 11 (1990) 835-861.

[41] K.R. Harris, L.A. Woolf, J. Chem. Eng. Data 49 (2004) 1064-1069.

[42] K.R. Harris, S. Bair, J. Chem. Eng. Data 52 (2006) 272-278.

[43] K.R. Harris, J. Chem. Eng. Data 54 (2009) 2729-2738.

[44] M.J.P. Comuñas, X. Paredes, F.M. Gaciño, J. Fernández, J.P. Bazile, C. Boned, J.L. Daridon, G. Galliero, J. Pauly, K.R. Harris, M.J. Assael, S.K. Mylona, J. Phys. Chem. Ref. Data 42 (2013) 033101.

[45] S.K. Mylona, M.J. Assael, M.J.P. Comuñas, X. Paredes, F.M. Gaciño, J. Fernández, J.P. Bazile, C. Boned, J.L. Daridon, G. Galliero, J. Pauly, K.R. Harris, J. Phys. Chem. Ref. Data 43 (2014) 013104.

[46] M.J. Assael, J.H. Dymond, M. Papadaki, P.M. Patterson, Int J Thermophys 13 (1992) 269-281.

[47] T. Regueira, L. Lugo, J. Fernández, Lubr. Sci. 26 (2014) 488-499.

[48] F.M. Gaciño, T. Regueira, M.J.P. Comuñas, J. Fernández, Volumetric Properties of a Pyrrolidinium-based and Two Imidazolium-based Ionic Liquids at High Pressures, International Workshop on Ionic Liquids- Seeds for New Engineering Applications, Lisbon (Portugal), 2012. [49] P.S. Kulkarni, L.C. Branco, J.G. Crespo, M.C. Nunes, A. Raymundo, C.A.M. Afonso, Chem. Eur. J. 13 (2007) 8478-8488.

[50] X. Wang, M. Sternberg, F.T.U. Kohler, B.U. Melcher, P. Wasserscheid, K. Meyer, R. Soc. Chem. Adv. 4 (2014) 12476-12481.

[51] X. Wang, F.W. Heinemann, M. Yang, B.U. Melcher, M. Fekete, A.-V. Mudring, P. Wasserscheid, K. Meyer, Chem. Commun. (2009) 7405-7407.

[52] T. Regueira, L. Lugo, M.J.P. Comuñas, J. Fernández, High pressure rheometric characterization of a polybutene, Rheology Trends: from nano to macro systems (IbeReo 2011), Caparica (Portugal), 2011. 
[53] T. Regueira, M.J.P. Comuñas, L. Lugo, X. Paredes, J. Fernández, Implementation of a Concentric Cylinder Rheometer for High Pressures, 19th European Conference on Thermophysical Properties (ECTP), Thessaloniki (Greece), 2011.

[54] M. Comuñas, A. Baylaucq, C. Boned, J. Fernández, Int J Thermophys 22 (2001) 749768.

[55] R. Errichello, Selecting oils with high pressure-viscosity coefficient - Increase bearing life by more than four times, Machinery Lubrication, 2004.

[56] S. Bair, Y. Liu, Q.J. Wang, J. Tribol. 128 (2006) 624-631.

[57] X. Paredes, O. Fandiño, A.S. Pensado, M.J.P. Comuñas, J. Fernández, Tribol Lett 45 (2012) 89-100.

[58] J. Fernández, X. Paredes, F.M. Gaciño, M.J.P. Comuñas, A.S. Pensado, Lubr. Sci. 26 (2014) 449-462.

[59] Experimental Thermodynamics Volume IX: Advances in Transport Properties of Fluids, RSC, 2014.

[60] A.S. Pensado, A.A.H. Pádua, M.J.P. Comuñas, J. Fernández, J. Phys. Chem. B 112 (2008) 5563-5574.

[61] E.R. López, A.S. Pensado, M.J.P. Comuñas, A.A.H. Pádua, J. Fernández, K.R. Harris, J. Chem. Phys. 134 (2011) -.

[62] H.R. Corti, M.P. Longinotti, J. Fernández, E.R. López, A. Würger, Dense Fluids: Other Developments. in: M.J. Assael, A.R.H. Goodwin, V. Vesovic, W.A. Wakeham, (Eds.), Experimental Thermodynamics Volume IX: Advances in Transport Properties of Fluids, RSC, 2014, pp. 288-336.

[63] R. Casalini, C.M. Roland, Phys. Rev. E 69 (2004) 062501.

[64] G. Tarjus, D. Kivelson, S. Mossa, C. Alba-Simionesco, J. Chem. Phys. 120 (2004) 61356141.

[65] R. Casalini, C.M. Roland, J. Non-Cryst. Solids 353 (2007) 3936-3939.

[66] M.J. Assael, J.H. Dymond, M. Papadaki, P.M. Patterson, Fluid Phase Equilibr. 75 (1992) 245-255.

[67] M.J. Assael, J.H. Dymond, M. Papadaki, P.M. Patterson, Int J Thermophys 13 (1992) 659-669.

[68] M.J. Assael, J.H. Dymond, S.K. Polimatidou, Int J Thermophys 15 (1994) 189-201.

[69] M.J. Assael, J.H. Dymond, S.K. Polimatidou, Int J Thermophys 16 (1995) 761-772.

[70] M. Assael, A. Kalyva, K. Kakosimos, K. Antoniadis, Int J Thermophys 30 (2009) 17331747.

[71] V. Vesovic, J.P.M. Trusler, M.J. Assael, N. Riesco, S.E. Quiñones-Cisneros, Dense Fluids: Viscosity. in: M.J. Assael, A.R.H. Goodwin, V. Vesovic, W.A. Wakeham, (Eds.), Experimental Thermodynamics Volume IX: Advances in Transport Properties of Fluids, RSC, 2014, pp. 253-287.

[72] F.M. Gaciño, M.J.P. Comuñas, J. Fernández, S.K. Mylona, M.J. Assael, Int J Thermophys (2014) 1-18.

[73] F. Ciotta, PhD Thesis, University of London, 2010. 
TABLE 1. Provenance and mass fraction purity of the ILs studied in this work.

\begin{tabular}{|c|c|c|c|c|}
\hline $\begin{array}{l}\text { Ionic Liquid } \\
\text { CAS Number }\end{array}$ & $\begin{array}{l}\text { Molecular structure } \\
\text { Cation Anion }\end{array}$ & Supplier & $\begin{array}{l}\text { Mole fraction } \\
\text { purity }\end{array}$ & $\begin{array}{l}\text { Mass } \\
\text { fraction } \\
\text { water } \\
\text { content }\end{array}$ \\
\hline $\begin{array}{l}{\left[\mathrm{C}_{4} \mathrm{C}_{1} \mathrm{Pyrr}\right]\left[\left(\mathrm{C}_{2} \mathrm{~F}_{5}\right)_{3} \mathrm{PF}\right.} \\
851856-47-8\end{array}$ & & $\begin{array}{l}\text { 1-butyl-1-methylpyrrolidinium } \\
\text { tris(pentafluoroethyl)trifluorophosphate }\end{array}$ & $>0.99^{*}$ & $5 \times 10^{-6}$ \\
\hline $\begin{array}{l}{\left[\mathrm{C}_{4} \mathrm{C}_{1} \mathrm{Pyrr}\right]\left[\mathrm{CF}_{3} \mathrm{SO}_{3}\right]} \\
367522-96-1\end{array}$ & & $\begin{array}{l}\text { 1-butyl-1-methylpyrrolidinium } \\
\text { trifluoromethanesulfonate }\end{array}$ & $>0.98^{*}$ & $12 \times 10^{-6}$ \\
\hline
\end{tabular}

* Mole fraction determined by electrophoresis. 


\section{TABLE 2}

Experimental viscosity values, $\eta / \mathrm{mPa} \cdot \mathrm{s}$ for the two ILs at different temperatures, $T$, and pressures, $p$ determined with the falling body viscometer

\begin{tabular}{|c|c|c|c|c|c|c|}
\hline \multirow[t]{2}{*}{$p / \mathrm{MPa}$} & \multicolumn{6}{|l|}{$T / \mathrm{K}$} \\
\hline & 303.15 & 313.15 & 323.15 & 333.15 & 343.15 & 353.15 \\
\hline & \multicolumn{6}{|c|}{$\left[\mathrm{C}_{4} \mathrm{C}_{1} \mathrm{Pyrr}\right]\left[\left(\mathrm{C}_{2} \mathrm{~F}_{5}\right)_{3} \mathrm{PF}_{3}\right]$} \\
\hline 10 & 189.5 & 113.5 & 73.4 & 48.0 & 33.9 & 24.7 \\
\hline 15 & 212.4 & 124.7 & 80.0 & 52.0 & 36.5 & 26.6 \\
\hline 25 & 265.5 & 150.6 & 94.9 & 61.0 & 42.2 & 30.7 \\
\hline 50 & 454.7 & 241.3 & 145.4 & 90.7 & 60.5 & 43.4 \\
\hline 75 & 765.1 & 386.8 & 222.6 & 134.3 & 86.9 & 60.6 \\
\hline 100 & 1274 & 620.3 & 340.5 & 198.1 & 124.5 & 84.1 \\
\hline 125 & 2111 & 995.1 & 520.9 & 291.7 & 178.5 & 116.0 \\
\hline \multirow[t]{2}{*}{150} & 3485 & 1597 & 797.0 & 429.1 & 255.8 & 159.3 \\
\hline & \multicolumn{6}{|c|}{$\left[\mathrm{C}_{4} \mathrm{C}_{1} \mathrm{Pyrr}\right]\left[\mathrm{CF}_{3} \mathrm{SO}_{3}\right]$} \\
\hline 10 & 144.8 & 89.2 & 58.9 & 41.7 & 29.9 & 22.5 \\
\hline 15 & 154.3 & 94.8 & 62.5 & 43.9 & 31.4 & 23.7 \\
\hline 25 & 174.9 & 106.9 & 70.2 & 48.6 & 34.7 & 26.1 \\
\hline 50 & 236.9 & 142.7 & 92.3 & 62.3 & 44.2 & 32.7 \\
\hline 75 & 317.7 & 188.1 & 119.5 & 79.0 & 55.7 & 40.5 \\
\hline 100 & 422.8 & 245.4 & 153.0 & 99.6 & 69.6 & 49.4 \\
\hline 125 & 559.5 & 318.1 & 194.1 & 124.9 & 86.4 & 59.9 \\
\hline 150 & 737.7 & 410.1 & 244.7 & 156.0 & 106.8 & 72.0 \\
\hline
\end{tabular}

Expanded uncertainties $(\mathrm{k}=2)$ are $\mathrm{U}(T)= \pm 0.1 \mathrm{~K}, \mathrm{U}(p)= \pm 0.2 \mathrm{MPa}$ and $\mathrm{U}(\eta)=3.5 \%$. 


\section{TABLE 3}

Parameters of the correlation equations

\begin{tabular}{|c|c|c|}
\hline & {$\left[\mathrm{C}_{4} \mathrm{C}_{1} \mathrm{Pyrr}\right]\left[\left(\mathrm{C}_{2} \mathrm{~F}_{5}\right)_{3} \mathrm{PF}_{3}\right]$} & {$\left[\mathrm{C}_{4} \mathrm{C}_{1} \mathrm{Pyrr}\right]\left[\mathrm{CF}_{3} \mathrm{SO}_{3}\right]$} \\
\hline & Equation (4) & \\
\hline$A / \mathrm{mPa} \cdot \mathrm{s}$ & 0.12806 & 0.14000 \\
\hline$B / \mathrm{K}$ & 916.61 & 939.41 \\
\hline$C / \mathrm{K}$ & 174.57 & 165.64 \\
\hline$D$ & 184.17 & 13.730 \\
\hline$E_{0} / \mathrm{MPa}$ & 3491.9 & -1426.7 \\
\hline$E_{1} / \mathrm{MPa}$ & -50.32 & 7.7957 \\
\hline $10^{2} \cdot E_{2} / \mathrm{MPa}$ & 22.45 & 0.1899 \\
\hline $\mathrm{AAD} / \%$ & 0.7 & 0.6 \\
\hline Bias/\% & -0.1 & -0.2 \\
\hline $\mathrm{MaxD} / \%$ & $\begin{array}{l}3.4 \\
\text { Equation (5) }\end{array}$ & 2.7 \\
\hline$a$ & -1.8699 & -1.9201 \\
\hline $10^{3} \cdot b / \mathrm{MPa}^{-1}$ & -5.094 & -0.2739 \\
\hline$c / \mathrm{K}$ & 865.21 & 922 \\
\hline$d / \mathrm{K}_{5} \mathrm{MPa}^{-1}$ & 3.2579 & 1.7275 \\
\hline $10^{5} \mathrm{e} / \mathrm{K} \cdot \mathrm{MPa}^{-2}$ & -27.72 & -72.590 \\
\hline$T_{0} / \mathrm{K}$ & 178.36 & 167.14 \\
\hline $\mathrm{AAD} / \%$ & 0.7 & 0.6 \\
\hline Bias/\% & 0.0 & 0.0 \\
\hline $\mathrm{MaxD} / \%$ & 2.9 & 2.4 \\
\hline$a$ & -2.179 & -1.9379 \\
\hline $10^{3}$ & 4.161 & 3.469 \\
\hline$c$ & 5.518 & 5.5748 \\
\hline$d / \mathrm{K}$ & 172.2 & 166.54 \\
\hline $10^{2} \cdot e / \mathrm{K} \cdot \mathrm{MPa}^{-1}$ & 17.03 & 9.857 \\
\hline $10^{5} \cdot f / \mathrm{K} \cdot \mathrm{MPa}^{-2}$ & -19.32 & -10.75 \\
\hline $\mathrm{AAD} / \%$ & 1.6 & 0.7 \\
\hline Bias/\% & -1.2 & 0.0 \\
\hline $\mathrm{MaxD} / \%$ & $\begin{array}{l}5.3 \\
\text { Equation (7) }\end{array}$ & 2.9 \\
\hline$a$ & -0.3813 & -0.1164 \\
\hline $10^{3} \cdot b / \mathrm{MPa}^{-1}$ & 1.0240 & 3.122 \\
\hline $10^{-6} \cdot c / \mathrm{K}^{3}$ & 152.10 & 138.80 \\
\hline $10^{-6} \cdot d / \mathrm{K}^{3} \cdot \mathrm{MPa}^{-1}$ & 0.54240 & 0.2567 \\
\hline
\end{tabular}




\begin{tabular}{lll}
$e / \mathrm{K}^{3} \cdot \mathrm{MPa}^{-2}$ & -1.9469 & -145.18 \\
$\mathrm{AAD} / \%$ & 1.3 & 0.8 \\
$\mathrm{Bias} / \%$ & 0.0 & -0.1 \\
$\mathrm{MaxD} / \%$ & 6.7 & 2.9 \\
\hline
\end{tabular}

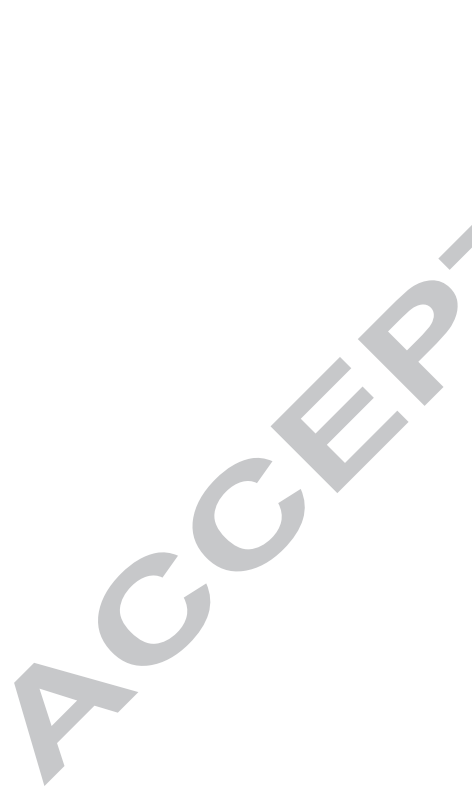




\section{TABLE 4}

Pressure-viscosity coefficients, $\alpha(p) / \mathrm{GPa}^{-1}$, and temperature-viscosity coefficients, $\beta(T) / \mathrm{K}^{-1}$, for the ILs measured in this work.

\begin{tabular}{|c|c|c|c|c|c|c|}
\hline \multirow[t]{2}{*}{$p / \mathrm{MPa}$} & \multicolumn{6}{|l|}{$T / \mathrm{K}$} \\
\hline & 303.15 & 313.15 & 323.15 & 333.15 & 343.15 & 353.15 \\
\hline & \multicolumn{6}{|c|}{$\left[\mathrm{C}_{4} \mathrm{C}_{1} \mathrm{Pyrr}\right]\left[\left(\mathrm{C}_{2} \mathrm{~F}_{5}\right)_{3} \mathrm{PF}_{3}\right]$} \\
\hline & \multicolumn{6}{|c|}{$\alpha(p) / \mathrm{GPa}^{-1}$} \\
\hline 10 & 20.7 & 18.9 & 17.2 & 15.8 & 14.5 & 13.4 \\
\hline 50 & 20.6 & 18.8 & 17.2 & 15.7 & 14.5 & 3.4 \\
\hline 100 & 20.5 & 18.7 & 17.1 & 15.7 & 14.4 & 13.3 \\
\hline 150 & 20.4 & 18.6 & 17.0 & 15.6 & 14.4 & 13.3 \\
\hline \multicolumn{7}{|c|}{$\beta(T) / \mathrm{K}^{-1}$} \\
\hline 10 & 57.4 & 49.5 & 43.0 & 37.8 & 33.4 & 29.8 \\
\hline 50 & 65.4 & 56.4 & 49.1 & 43.1 & 38.2 & 34.0 \\
\hline 100 & 75.3 & 65.0 & 56.7 & 49.8 & 44.1 & 39.2 \\
\hline 150 & 85.1 & 73.6 & 64.2 & 56.4 & 49.9 & 44.4 \\
\hline \multicolumn{7}{|c|}{$\left[\mathrm{C}_{4} \mathrm{C}_{1} \mathrm{Pyrr}\right]\left[\mathrm{CF}_{3} \mathrm{SO}_{3}\right]$} \\
\hline \multicolumn{7}{|c|}{$\alpha(p) / \mathrm{GPa}^{-1}$} \\
\hline 10 & 12.2 & 11.3 & 10.6 & 9.9 & 9.3 & 8.7 \\
\hline 50 & 11.8 & 11.0 & 10.2 & 9.6 & 9.0 & 8.5 \\
\hline 100 & 11.3 & 10.6 & 9.9 & 9.3 & 8.7 & 8.3 \\
\hline 150 & 10.9 & & 9.5 & 9.0 & 8.5 & 8.0 \\
\hline \multicolumn{7}{|c|}{$\beta(T) / \mathrm{K}^{-1}$} \\
\hline 10 & 50.7 & 44.0 & 38.6 & 34.1 & 30.4 & 27.2 \\
\hline 50 & 54.4 & 47.3 & 41.4 & 36.6 & 32.6 & 29.2 \\
\hline 100 & 58.8 & 51.1 & 44.8 & 39.6 & 35.2 & 31.5 \\
\hline 150 & 62.8 & 54.6 & 47.8 & 42.3 & 37.7 & 33.7 \\
\hline
\end{tabular}




\section{TABLE 5}

Universal pressure-viscosity coefficient, reciprocal asymptotic isoviscous pressure and product $\eta_{0}^{0.69} \alpha_{\text {film }}^{0.56}$ for the two ILs studied in this work at several temperatures.

\begin{tabular}{lllllll}
\hline \multirow{2}{*}{$T / \mathrm{K}$} & \multicolumn{3}{l}{$\left[\mathrm{C}_{4} \mathrm{C}_{1} \mathrm{Pyrr}\right]\left[\left(\mathrm{C}_{2} \mathrm{~F}_{5}\right)_{3} \mathrm{PF}_{3}\right]$} & \multicolumn{3}{l}{$\left[\mathrm{C}_{4} \mathrm{C}_{1} \mathrm{Pyrr}\right]\left[\mathrm{CF}_{3} \mathrm{SO}_{3}\right]$} \\
\cline { 2 - 7 } & $\alpha_{\mathrm{film}} / \mathrm{GPa}^{-1}$ & $\alpha^{*} / \mathrm{GPa}^{-1}$ & $\eta_{0}^{0.69} \alpha_{\text {film }}^{0.56}$ & $\alpha_{\text {film }} / \mathrm{GPa}^{-1}$ & $\alpha^{*} / \mathrm{GPa}^{-1}$ & $\eta_{0}^{0.69} \alpha_{\text {film }}^{0.56}$ \\
\hline 303.15 & 20.8 & 20.6 & 181.2 & 11.7 & 11.5 & 113.7 \\
313.15 & 18.9 & 18.8 & 120.5 & 10.8 & 10.6 & 79.0 \\
323.15 & 17.3 & 17.2 & 84.2 & 10.0 & 9.9 & 57.4 \\
333.15 & 15.8 & 15.7 & 61.4 & 9.4 & 9.2 & 43.3 \\
343.15 & 14.5 & 14.5 & 46.2 & 8.8 & 8.7 & 33.6 \\
353.15 & 13.4 & 13.3 & 35.9 & 8.3 & 8.2 & 26.7 \\
\hline
\end{tabular}

$\alpha_{\text {film }}$ and $\alpha^{*}$ are reported in $\mathrm{GPa}^{-1}$; and $\eta_{0}$ in $\mathrm{mPa} \cdot \mathrm{s}$. 


\section{TABLE 6}

Characteristic parameters $\left(\eta_{0}, A, \gamma, \phi\right)$ for equation (17) and average absolute deviations (AAD) of the correlation.

\begin{tabular}{llllll}
\hline $\mathrm{IL}$ & $\eta_{0} / \mathrm{mPa} \cdot \mathrm{s}$ & $A /\left(\mathrm{K} \cdot \mathrm{g}^{-\gamma} \cdot \mathrm{cm}^{3 \cdot \gamma}\right)$ & $\gamma$ & $\phi$ & $\mathrm{AAD} / \%$ \\
\hline$\left[\mathrm{C}_{4} \mathrm{C}_{1} \mathrm{Pyrr}\right]\left[\left(\mathrm{C}_{2} \mathrm{~F}_{5}\right)_{3} \mathrm{PF}_{3}\right]$ & 2.8353 & 77.64 & 4.32 & 2.26 & 1.7 \\
{$\left[\mathrm{C}_{4} \mathrm{C}_{1} \mathrm{Pyrr}\right]\left[\mathrm{CF}_{3} \mathrm{SO}_{3}\right]$} & 1.4198 & 306.6 & 3.17 & 2.09 & 1.4 \\
\hline
\end{tabular}




\section{TABLE 7}

Hard-sphere scheme parameters and average absolute deviations (AAD) of the correlation for the ILs under study.

\begin{tabular}{llllll}
\hline $\mathrm{IL}$ & $\begin{array}{l}10^{4} \cdot d_{0} / \\
\mathrm{m}^{3} \cdot \mathrm{mol}^{-1}\end{array}$ & $\begin{array}{l}10^{7} \cdot d_{1} / \\
\mathrm{m}^{3} \cdot \mathrm{mol}^{-1} \cdot \mathrm{K}^{-1}\end{array}$ & $\begin{array}{l}d_{2} / \\
\mathrm{m}^{3} \cdot \mathrm{mol}^{-1} \cdot \mathrm{K}^{-2}\end{array}$ & $\begin{array}{l}\mathrm{R}_{\eta} \\
\text { AAD/ } \\
\%\end{array}$ \\
\hline$\left[\mathrm{C}_{4} \mathrm{C}_{1} \mathrm{Pyrr}\right]\left[\left(\mathrm{C}_{2} \mathrm{~F}_{5}\right)_{3} \mathrm{PF}_{3}\right]$ & 4.34114 & -5.7945 & 5.83109 & 3.5 & 2.0 \\
{$\left[\mathrm{C}_{4} \mathrm{C}_{1} \mathrm{Pyrr}\right]\left[\mathrm{CF}_{3} \mathrm{SO}_{3}\right]$} & 2.60079 & -2.7275 & 1.50428 & 6.7 & 1.7 \\
\hline
\end{tabular}




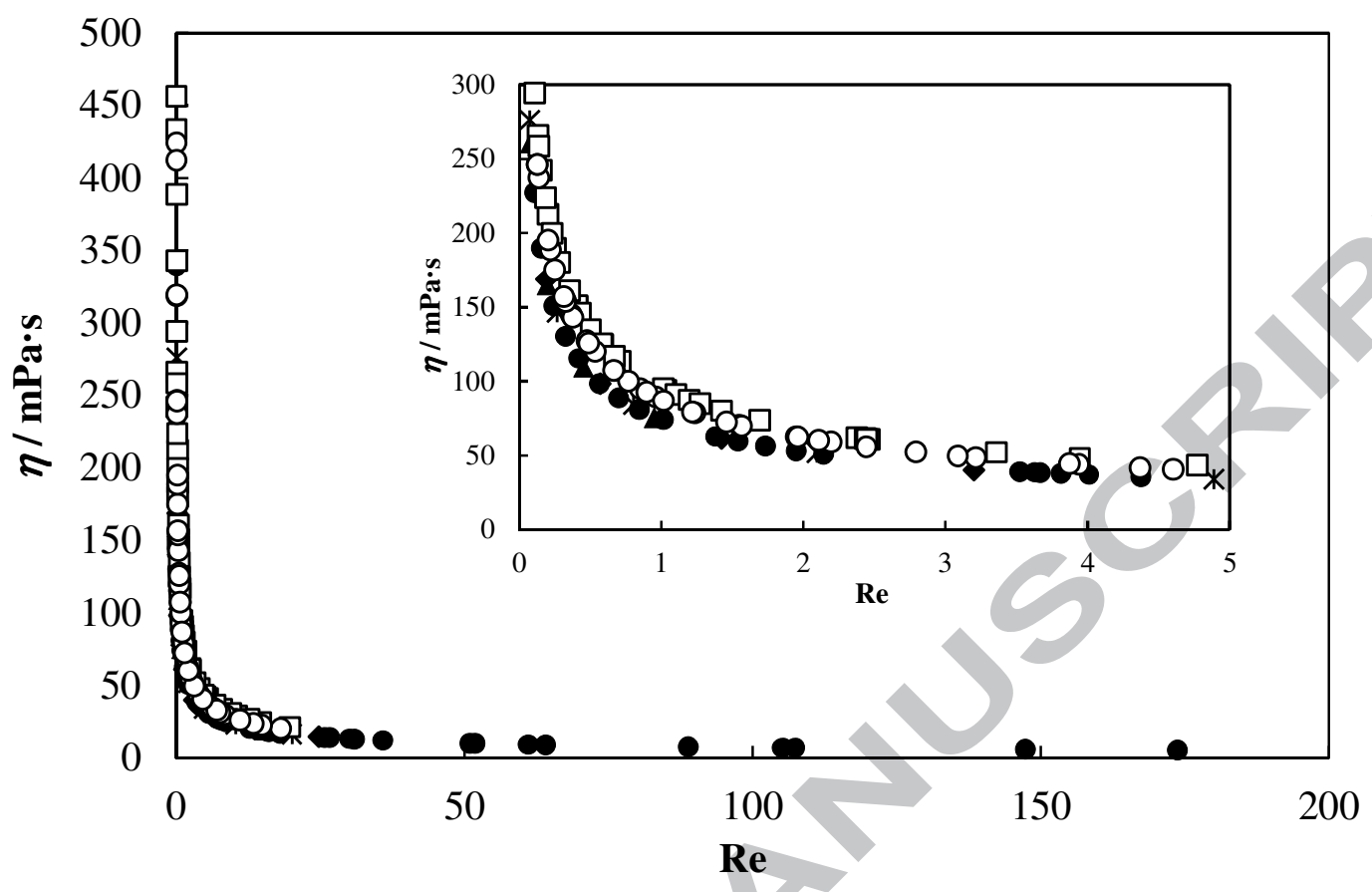

FIGURE 1. Plot of viscosity against Reynolds number obtained with the VisLPT1 for:

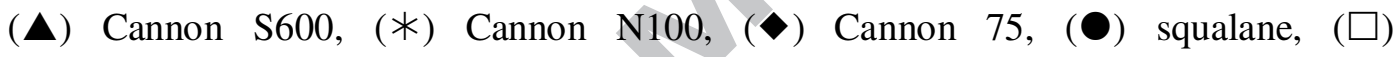
$\left[\mathrm{C}_{4} \mathrm{C}_{1} \mathrm{Pyrr}\right]\left[\left(\mathrm{C}_{2} \mathrm{~F}_{5}\right)_{3} \mathrm{PF}_{3}\right]$ and $(\mathrm{O})\left[\mathrm{C}_{4} \mathrm{C}_{1} \mathrm{Pyrr}\right]\left[\mathrm{CF}_{3} \mathrm{SO}_{3}\right]$. 

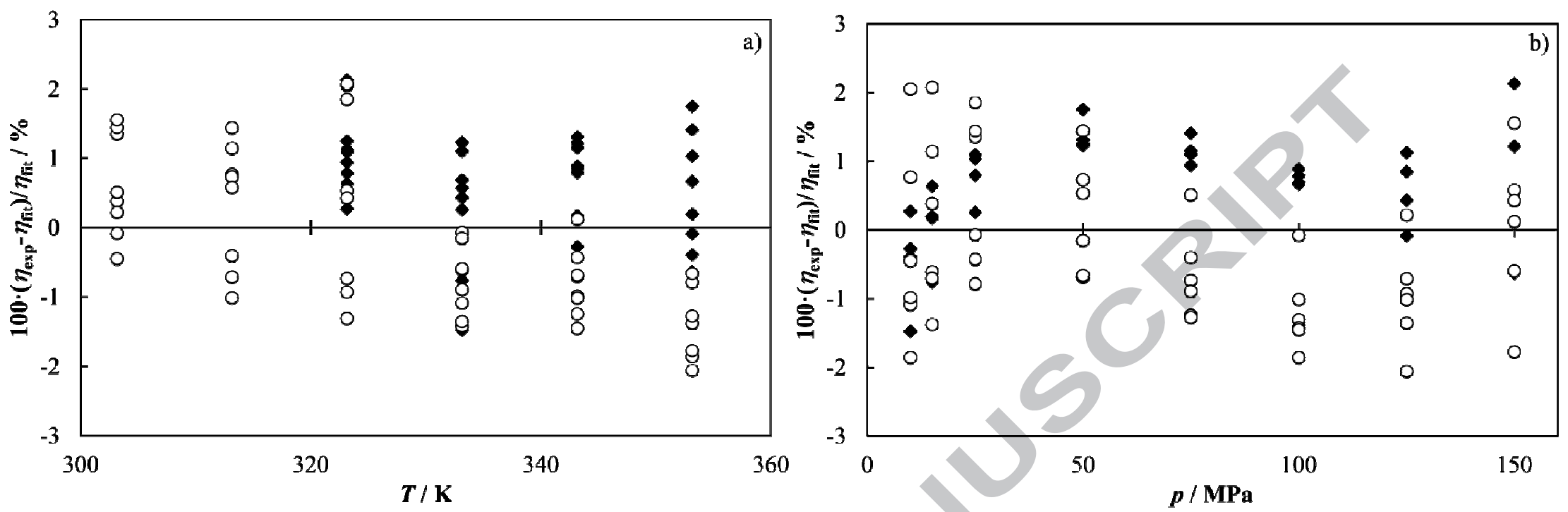

FIGURE 2. Comparison between viscosity values for squalane of this work with correlations proposed by Mylona et al. [45] ( $\bullet$ ) correlation based on hard-spheres scheme and $(\bigcirc)$ correlation based on the modified VFT model. 

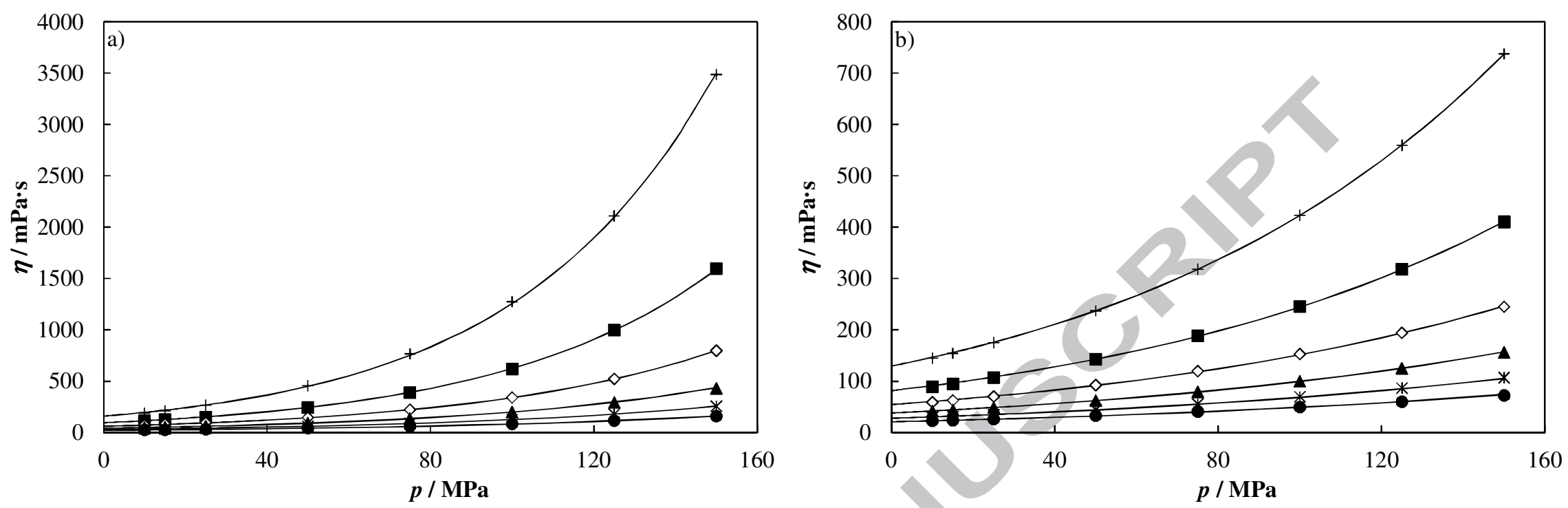

FIGURE 3. Experimental viscosity values as a function of pressure for a) $\left[\mathrm{C}_{4} \mathrm{C}_{1} \mathrm{Pyrr}\right]\left[\left(\mathrm{C}_{2} \mathrm{~F}_{5}\right)_{3} \mathrm{PF}_{3}\right]$ and b) $\left[\mathrm{C}_{4} \mathrm{C}_{1} \mathrm{Pyrr}\right]\left[\mathrm{CF}_{3} \mathrm{SO}_{3}\right]$. $(\times) T=313.15$ $\mathrm{K},(\boldsymbol{\square}) T=313.15 \mathrm{~K},(\diamond) T=323.15 \mathrm{~K},(\boldsymbol{\Delta}) \mathrm{T}=333.15 \mathrm{~K},(*) T=343.15 \mathrm{~K}$ and $(\bullet) T=353.15 \mathrm{~K}$. The solid lines represent the values obtained using equation (4). 

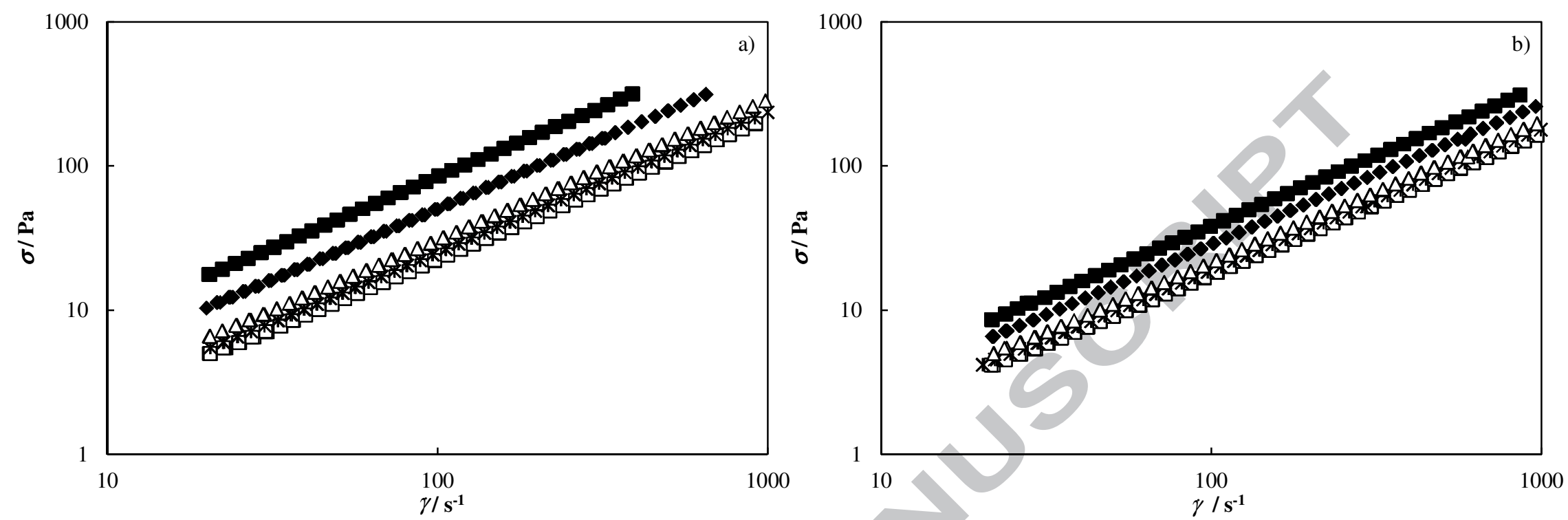

FIGURE 4. Flow curves at $T=303.15 \mathrm{~K}$ for a) $\left[\mathrm{C}_{4} \mathrm{C}_{1} \mathrm{Pyrr}\right]\left[\left(\mathrm{C}_{2} \mathrm{~F}_{5}\right)_{3} \mathrm{PF}_{3}\right]$ and b) $\left[\mathrm{C}_{4} \mathrm{C}_{1} \mathrm{Pyrr}\right]\left[\mathrm{CF}_{3} \mathrm{SO}_{3}\right]$. ( $\left.\square\right) \mathrm{p}=10 \mathrm{MPa},(\times) \mathrm{p}=15 \mathrm{MPa},(\triangle) 25$ $\mathrm{MPa},(\diamond) 50 \mathrm{MPa},(\square) \mathrm{p}=75 \mathrm{MPa}$. 


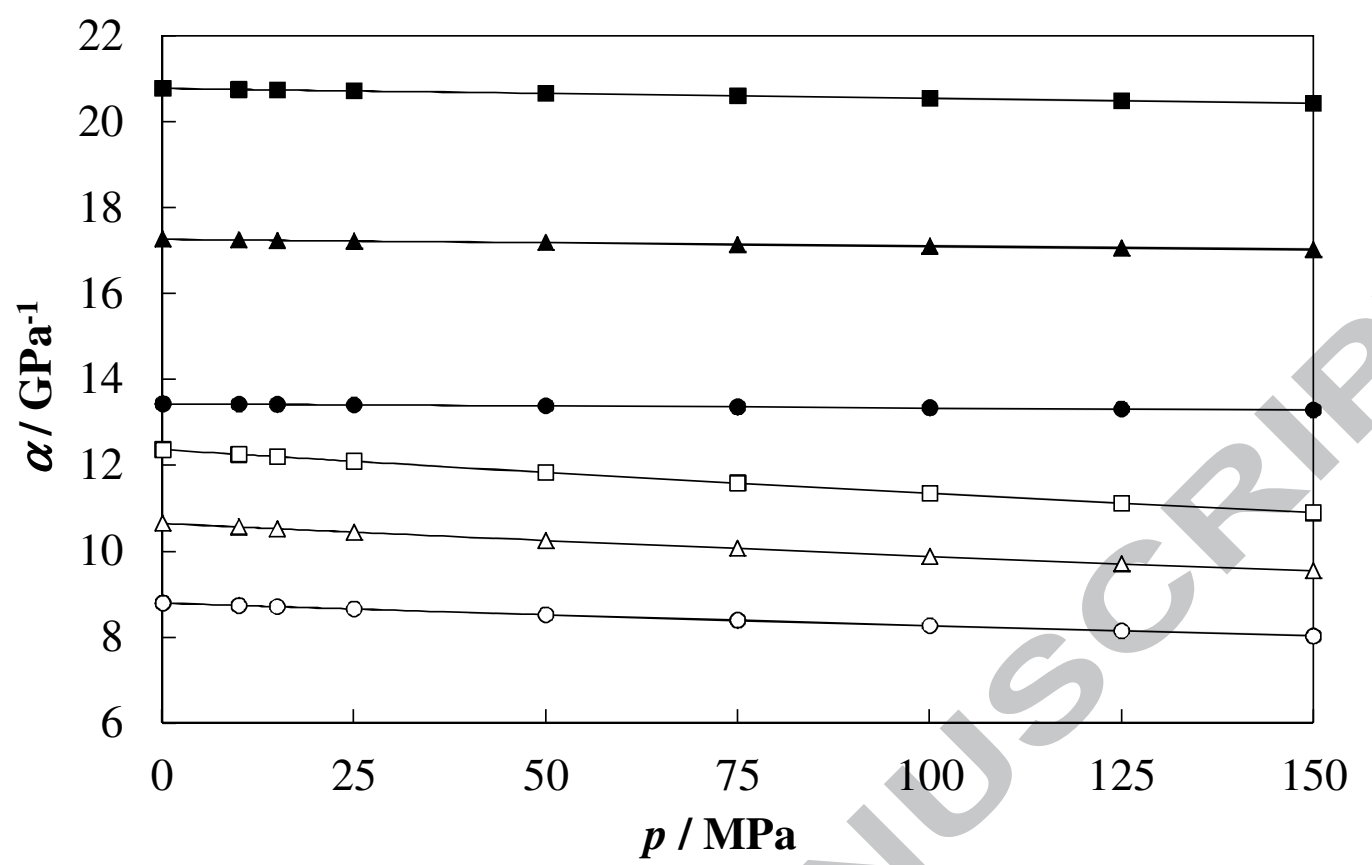

FIGURE 5. Local pressure-viscosity coefficient as a function of pressure for $\left[\mathrm{C}_{4} \mathrm{C}_{1} \mathrm{Pyrr}\right]\left[\left(\mathrm{C}_{2} \mathrm{~F}_{5}\right)_{3} \mathrm{PF}_{3}\right]$ (filled symbols) and $\left[\mathrm{C}_{4} \mathrm{C}_{1} \mathrm{Pyrr}\right]\left[\mathrm{CF}_{3} \mathrm{SO}_{3}\right]$ (empty symbols). (a) $T=303.15 \mathrm{~K},(\mathbf{\Delta}) 323.15 \mathrm{~K}$ and $(\mathbf{O}) 353.15 \mathrm{~K}$. 


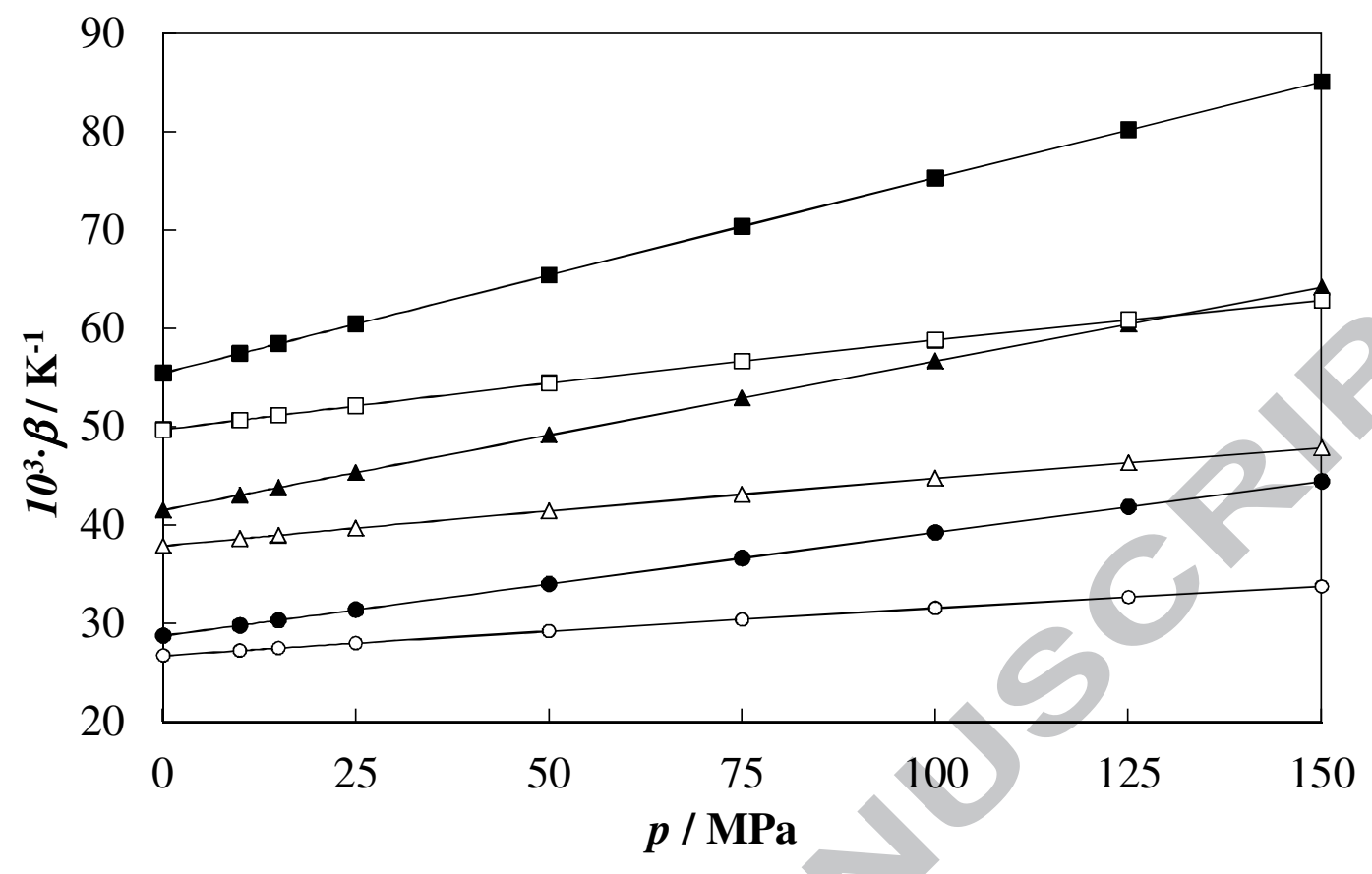

FIGURE 6. Local temperature-viscosity coefficient as a function of pressure for $\left[\mathrm{C}_{4} \mathrm{C}_{1} \mathrm{Pyrr}\right]\left[\left(\mathrm{C}_{2} \mathrm{~F}_{5}\right)_{3} \mathrm{PF}_{3}\right]$ (filled symbols) and $\left[\mathrm{C}_{4} \mathrm{C}_{1} \mathrm{Pyrr}\right]\left[\mathrm{CF}_{3} \mathrm{SO}_{3}\right]$ (empty symbols). (ם) $T=303.15 \mathrm{~K},(\mathbf{\Delta}) 323.15 \mathrm{~K}$ and $(\boldsymbol{O}) 353.15 \mathrm{~K}$. 


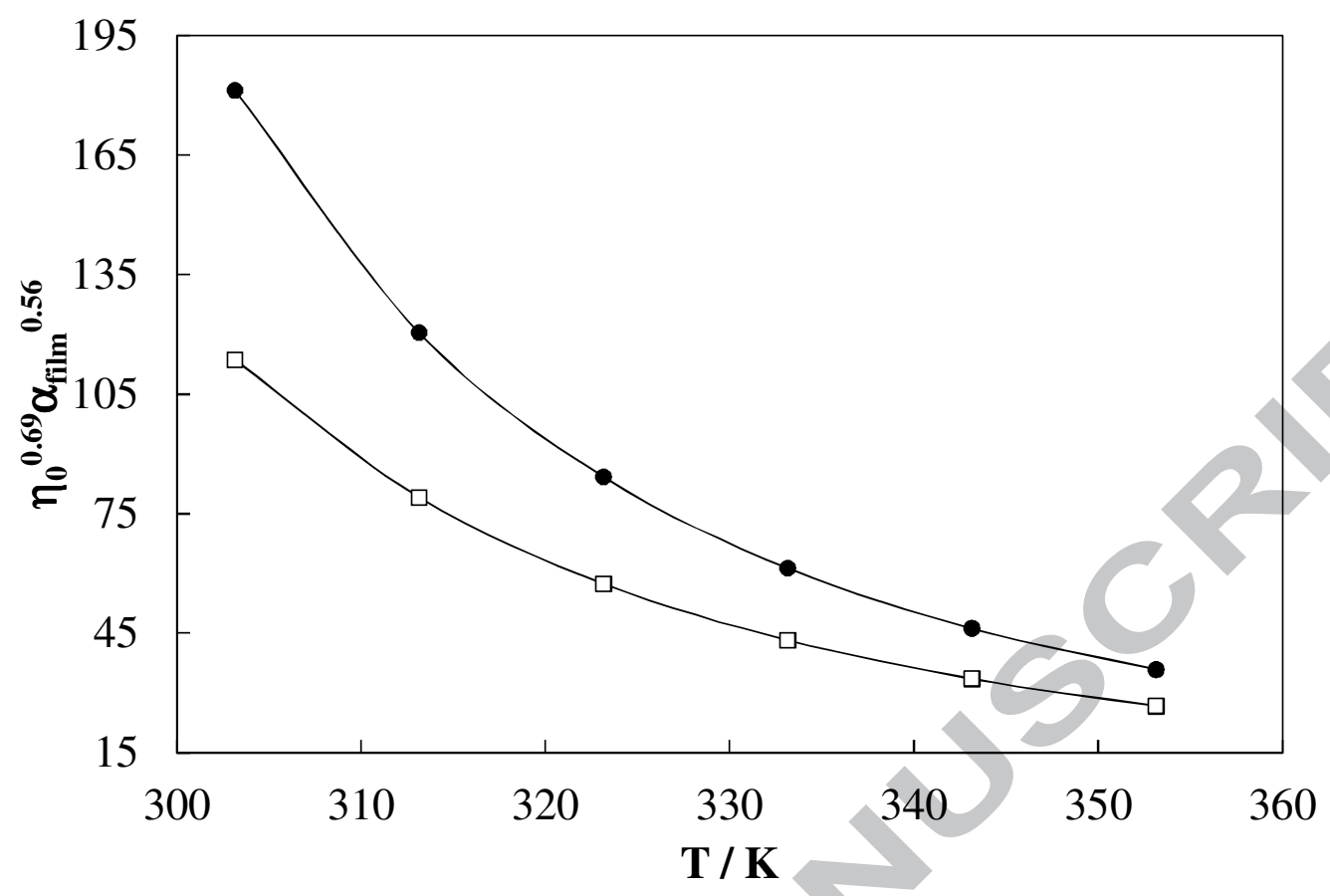

FIGURE 7. Film thickness factor due to the lubricant, $\eta_{0}^{0.69} \alpha_{\text {film }}^{0.56}$ as a function of temperature for $\left[\mathrm{C}_{4} \mathrm{C}_{1} \mathrm{Pyrr}\right]\left[\left(\mathrm{C}_{2} \mathrm{~F}_{5}\right)_{3} \mathrm{PF}_{3}\right](\mathrm{O})$ and $\left[\mathrm{C}_{4} \mathrm{C}_{1} \mathrm{Pyrr}\right]\left[\mathrm{CF}_{3} \mathrm{SO}_{3}\right](\square)$. 


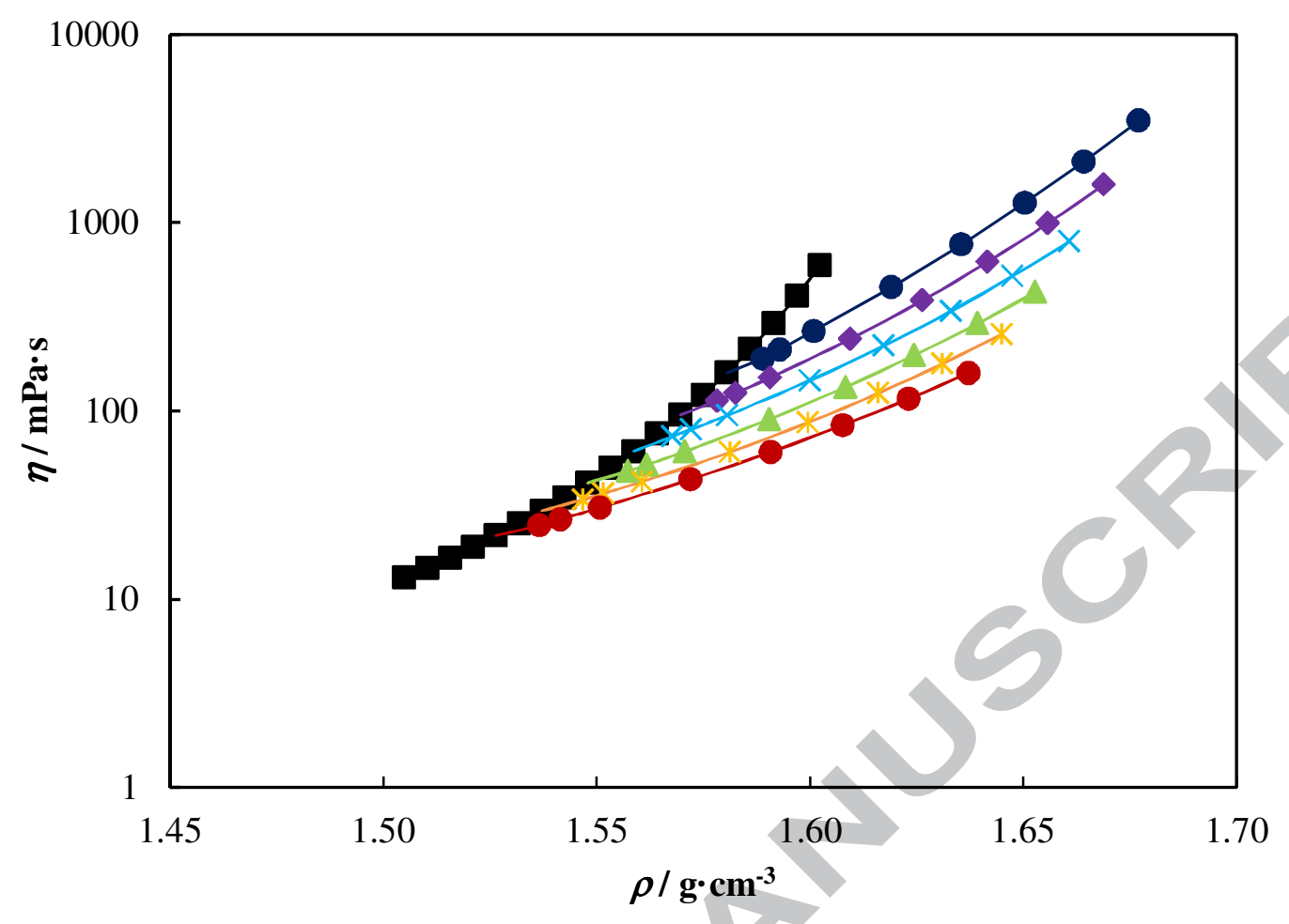

FIGURE 8. Viscosity of $\left[\mathrm{C}_{4} \mathrm{C}_{1} \mathrm{Pyrr}\right]\left[\left(\mathrm{C}_{2} \mathrm{~F}_{5}\right)_{3} \mathrm{PF}_{3}\right]$ against density. (ם) $0.1 \mathrm{MPa},(\mathbf{O}) T=$ $303.15 \mathrm{~K},(\diamond) 313.15 \mathrm{~K},(\times) 323.15 \mathrm{~K},(\boldsymbol{\bullet}) 333.15 \mathrm{~K},(*) 343.15 \mathrm{~K},(\bullet) 353.15 \mathrm{~K}$. 


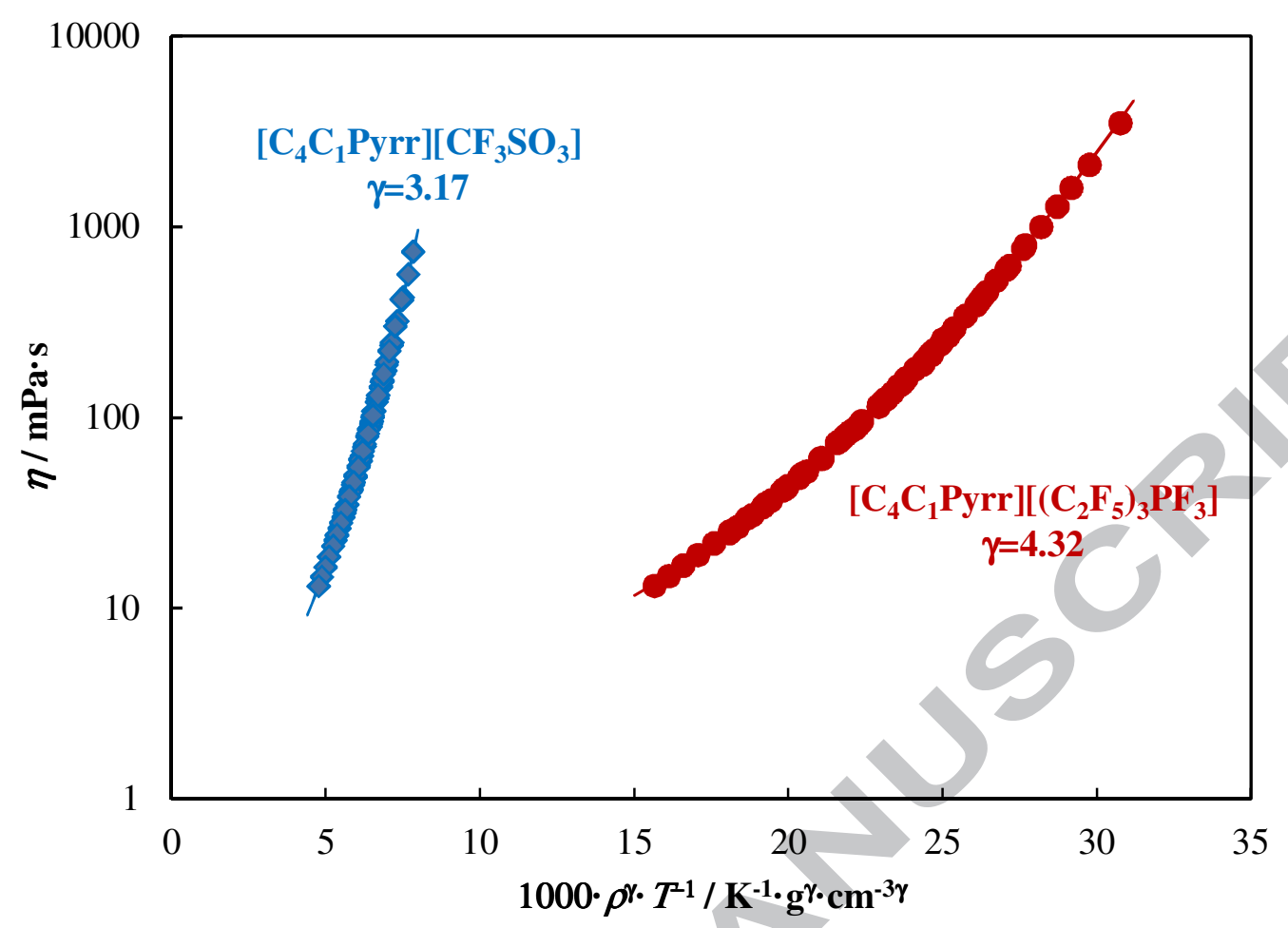

FIGURE 9. Superposition of the viscosity $\eta$ of the ILs studied by fitting the $\gamma$ values to the experimental results. The solid lines are the correlations using the equation (17). 


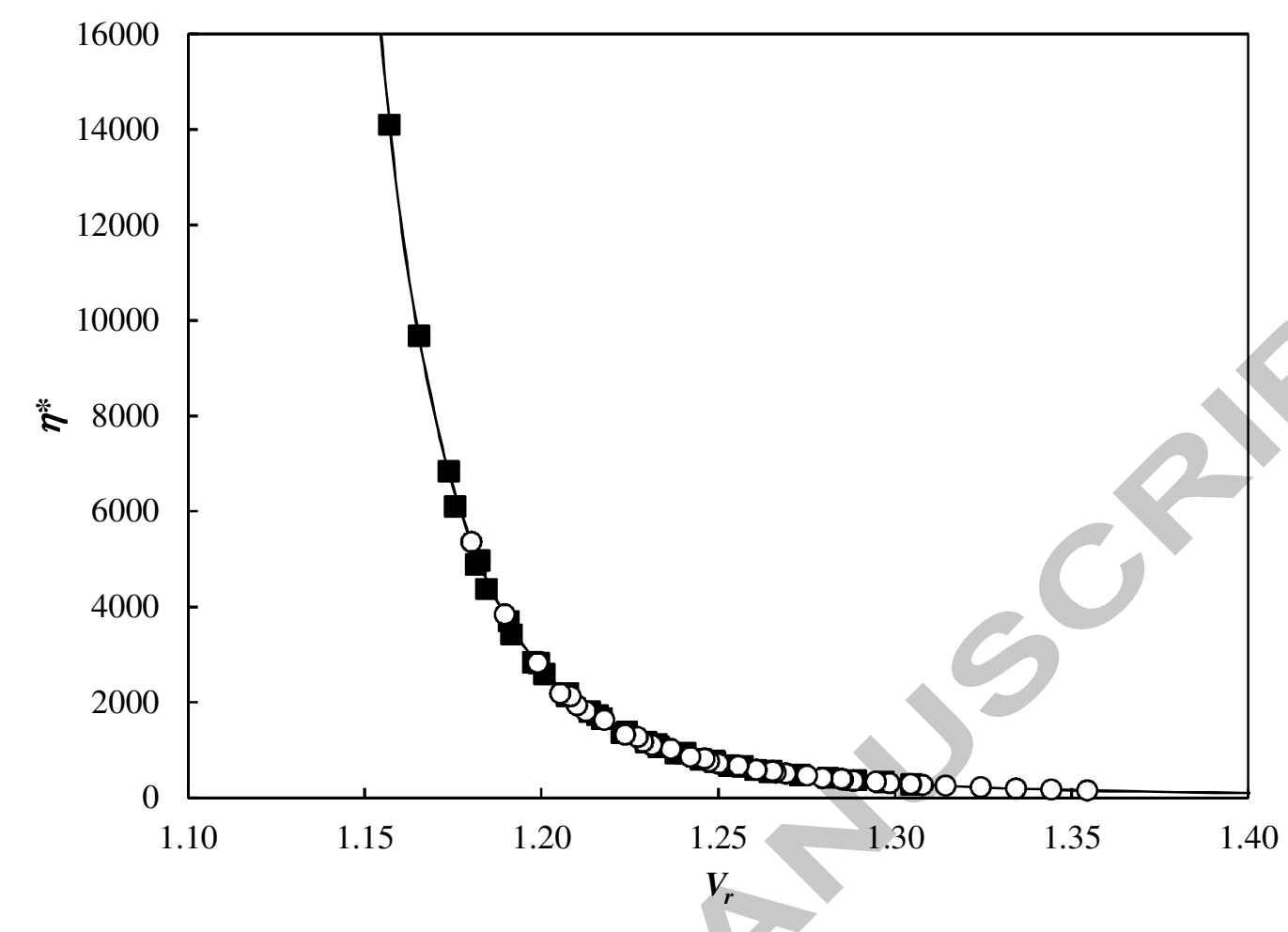

FIGURE 10. Reduced viscosity values of $\left[\mathrm{C}_{4} \mathrm{C}_{1} \mathrm{Pyrr}\right]\left[\left(\mathrm{C}_{2} \mathrm{~F}_{5}\right)_{3} \mathrm{PF}_{3}\right]$ ( $\left.\mathbf{\square}\right)$ and $\left[\mathrm{C}_{4} \mathrm{C}_{1}\right.$ Pyrr $]\left[\mathrm{CF}_{3} \mathrm{SO}_{3}\right](\mathrm{O})$ obtained using experimental viscosities, equations 18 and 19 with $d_{i}$ parameters from table 7 . The solid line is the universal curve proposed by Ciotta [73]. 


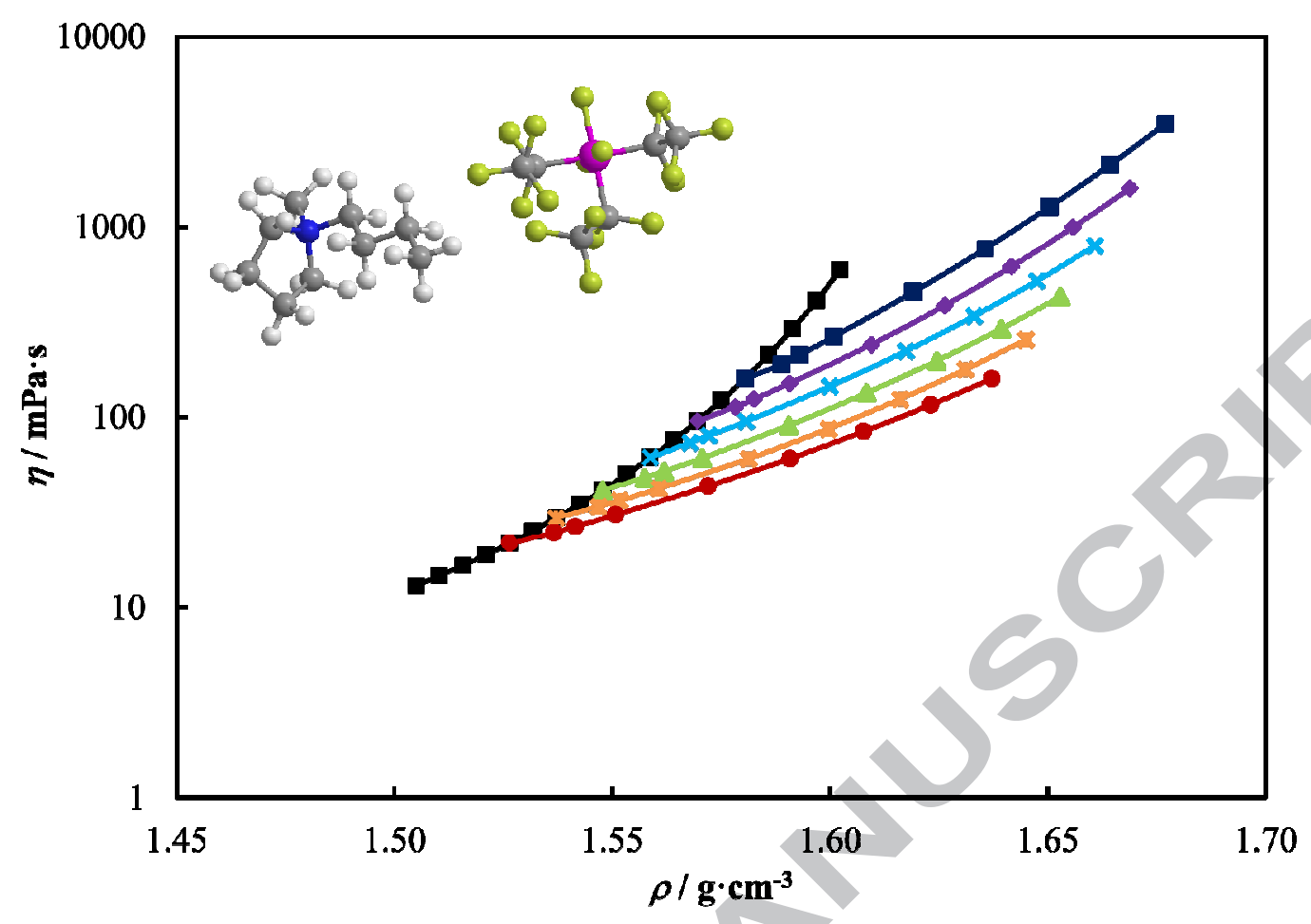


Uncertainty of a falling body viscometer is improved by means of a new calibration procedure and new temperature probes.

Viscosities with an uncertainty of $3.5 \%$ are reported for two ILs from 303.15 to $353.15 \mathrm{~K}$ at pressures up to $150 \mathrm{MPa}$.

Local pressure-viscosity and temperature-viscosity coefficients are analyzed for both ILs.

Thermodynamic scaling and hard spheres scheme are successfully applied to the viscosity values of both ILs. 